\title{
MEDİL (KÖKLÜ) MAĞARASI (AZDAVAY-KASTAMONU) VE TURİZM AÇISINDAN ÖNEMI*
}

Medil (Köklü) Cave (Azdavay-Kastamonu) and its Importance for Tourism

\author{
Dr. Öğr. Üye. Faruk AYLAR ${ }^{1}$ \\ Prof. Dr. Halil İbrahim ZEYBEK ${ }^{2}$ \\ Araş. Gör. Hasan DİNÇER ${ }^{3}$

 \\ $\ddot{\boldsymbol{O}} z$
}

Mağaralar jeolojik, jeomorfolojik, hidrografik özellikleri, kendilerine has floristik ve faunistik zenginlikleri, tarihi ve kültürel nitelikleri ile Türkiye'nin önemli turistik çekicilikleri arasında yer almaktadırlar. Ancak bu oluşumların sağllklı şekilde korunması ve sürdürülebilir yararlanma açısından potansiyellerinin belirlenmesi büyük önem taşımaktadır. Bu kapsamda doğal mă̆ara varlı̆̆ bakımından Türkiye’nin önemli illeri arasında yer alan Kastamonu büyük bir zenginliğe sahiptir. İlde arazisinin jeolojik, tektonik ve klimatik özelliklerine bağll olarak çok sayıda mağara bulunmaktadır. Pınarbaşı ilçesindeki Ilgarini ve Mantar mağaraları, Devrekani Illçesindeki Sarpunalınca ve Sisli-Gizemli mağaraları, Şenpazar ilçesindeki Kuyluç Mağarası, Cide ilçesindeki Kılıçlı Mağarası ve Azdavay ilçesindeki çalışmaya konu olan Medil mă̆arası ve Dă̆lı (Kuylucu) mă̆araları ilde turizm potansiyeli olan başlıca mă̆aralar olup, turizm açısından değerlendirilmeyi beklemektedirler.

Medil mă̆arası, Batı Karadeniz Bölümü'nde Kastamonu ilinin Azdavay ilçesine bağlı Karakuşlu köyünün Ayvat mahallesi sınırları içerisinde kalmaktadır. Devrekani Çayı'nın açtı̆̆ Çatak Kanyonu'nun hemen doğusunda yer alan mă̆aranın Azdavay ilçe merkezine uzaklı̆̆ yaklaşık 7,2 km'dir. Mă̆ara ă̆zının deniz seviyesinden yüksekliği ise $1046 \mathrm{~m}$ olarak ölçülmüş̧ür.

Mesozoik yaşlı (Üst Jura-Alt Kretase) kireçtaşları içerisinde oluşan Medil mă̆arası, damlataşı şekilleri yanında içerisindeki tarihi kalıntıları ile dikkati çekmektedir. Erken Roma dönemine ait olduğu düşünülen bu kalıntılar, Medil mağarasının uzun yıllar insanoğlu

* Bu çalışma Amasya Üniversitesi Bilimsel Araştırmalar Projeleri Koordinatörlüğü tarafından SEB-BAP 18-0165 nolu proje olarak desteklenmiştir.

${ }^{1}$ Amasya Üniversitesi Eğitim Fakültesi, Türkçe ve Sosyal Bilgiler Eğitimi Bölümü, farukaylar@gmail.com ORCID ID: 0000-0003-4439-9079

${ }^{2}$ Ondokuzmayıs Üniversitesi Fen Edebiyat Fakültesi, Coğrafya Bölümü, zeybekhi@gmail.com ODCID ID: 0000-0002-4097-9079

${ }^{3}$ Ondokuzmayıs Üniversitesi Fen Edebiyat Fakültesi, Coğrafya Bölümü, hasan.dincer@omu.edu.tr ODCID ID: 0000-0001-5015-3142 
tarafından bir barınak olarak kullanıldığını göstermektedir. Giriş kısmı ile măgaranın tabanı arasında yaklaşık 6 m'lik bir yükselti farkı vardır. Çok dar ve $30^{\circ}$ lik bir eğime sahip olan mağara girişi oldukça tehlikelidir. Giriş kısmından itibaren mă̆aranın farklı boyut ve yükseklikte dört ana salon ve bunları birbirine bağlayan galerilerden oluştuğu görülmüştür. Toplam uzunluğu 205 m olan Medil mağarasının içinde tarihi kalıntıların yanında sarkıt, dikit, sütun ve mă̆ara incileri gibi damlataşı şekilleri de bulunmaktadır. Doğal bir mikroklima alanı özelliği gösteren Medil mă̆arası, hidrolojik olarak yarı aktif bir mă̆aradır.

Medil mă̆arası, içerisinde barındırdiğı damlataş şekillerinin yanında tarihi ve kültürel özelliği ile de önemli bir turizm potansiyeline sahiptir. Kastamonu ilindeki mağara turizmi açısından önemli bir çekicilik taşıyan mağaranın, Çatak Kanyonu'na yakınlı̆̆ bu önemini arttırmaktadır. Mă̆aranın turizm potansiyelinin değerlendirilmesi için herhangi bir proje veya yatırım yapılmamıştır. Tırmanma, aydınlatma ve yürüyüş yolları başta olmak üzere yöreye gelen turistlerin mağarayı rahatlıkla gezebilecekleri donanımların yapılması gerekmektedir. Bununla birlikte mă̆arayı turizme kazandıracak tüm müdahalelerin doğal çevreyle uyumlu ve mağarada tahribata yol açmayacak şekilde planlanması gerekir.

Anahtar Kelimeler: Azdavay, Medil, Mağara, Kireçtaşı, Damlataşı, Turizm.

\section{Abstract}

Caves are important touristic attractions of Turkey related to their geological, geomorphological, hydrological structures with floristic and faunistic, historical and cultural features. However, it is important to determine their potentials when they are protected and to provide their sustainability. In this context, Kastamonu which is one of the cities in Turkey with the number of caves has a richness related to the number of caves. In the hinterland of the city, there are many caves related to the geological structure of the landscape, tectonic and climatic features. The important caves in the city are the Ilgarini and the Mantar caves in Pınarbaşl town, the Sarpunalinca and the Sisli-Gizemli caves in Devrekani town, the Kuyluç caves in Şenpazar town, the Kllıçl cave in Cide and the Medil cave and the Kırkbasamak cave in Azdavay town which becomes the theme of the research. These caves in Kastamonu have a great tourism potential and are waiting to be investigated and evaluated.

The Medil Cave is situated in Ayvat district of Karakuşlu town in Azdavay town of Kastamonu in the west part of Blacksea region. The distance of the cave to Devrekani is about 7,2 km and is located in the east part of the Çatak Canyon occurred on the Devrekani stream. The entrance of the cave is 1046 meters high from the sea level.

The Medil Cave has historical ruins inside and it is occurred in clay stones belonging Mesozoic age (Late Jurassic-Early Cretaceous). These ruins are thought belonging to the early Roman period and it proves that the cave has been used for protection for the people for a long time. The height of the cave is about 6 meters from the entrance to the basement. The entrance of the cave is very dangerous as the entrance is very narrow and it has $30^{\circ}$ inclination. There are four saloons with different heights starting from the entrance and the galleries between them connect them to each other. The length of the cave is $205 \mathrm{~m}$ and besides the historical ruins, there are stalactites, stalagmites and drop-shaped ornaments in the Medil Cave. It provides a natural microclimate feature and it is active as hydrological.

The Medil cave has a tourism potential with its cultural and historical features besides its drop-shaped ornaments. As it is very close to the Catak Canyon, the tourism potential becomes important. No protection measures have been taken for the evaluation of the cave. It is necessary to build climbing route for the visitors and the cave should be illuminated. However, it is essential to build an environment around the cave with the accordance of the landscape and the structure of the cave should be protected.

Keywords: Azdavay, Medil, Cave, Limestone, Dripstone, Tourism. 


\section{Giriş}

Mağaralar oluşum özelliği, kayaç ve mağaranın oluşum zamanı, içinde geliştikleri kayaç tipi, taban suyu seviyesi, yer altı suyu akışı gibi çeşitli kriterler bakımından sınıflandırılmaktadır. Oluşum özellikleri bakımından mağaralar doğal ve yapay mağaralar olarak iki büyük grupta toplanmaktadır. Dünyada ve ülkemizde doğal mağaralar içerisinde en yaygın olanları karstik mağaralardır.

Karstik çözünme sonucunda meydana gelen birbirinden farklı boyut ve türde oluşum gösteren çeşitli yer şekilleri içerisinde, yeraltındaki çözünme sürecine bağlı oluşan mağaralar karstik şekillerin en dikkat çekenlerinden birisidir (Doğu vd., 1995; 293: Uzun ve Zeybek, 1996; 40: Sever, 2008; 253). Karst rölyefinin yer altında oluşmuş en büyük şekilleri olan mağaralar, karbonatlı kayaçların sular tarafından eritilmesiyle oluşan, farklı damlataşı şekillerine sahip büyük yer altı boşluklarıdır (Zeybek, 2001; 239). Mağaralar sahip oldukları doğal özellikler sayesinde tarihin eski dönemlerinden itibaren insanlar tarafından değişik amaçlarla kullanılmışlar ve çeşitli araştırmalara konu olmuşlardır (Nazik, 1989;54: Uzun, 1991; 16: Uzun ve Zeybek, 1996; 40: Doğaner, 2001; 86: Ceylan ve Demirkaya, 2006; 201: Kopar, 2008; 72: Karadeniz vd., 2009; 1623: Arpacı vd., 2012; 62: Özşahin, 2013; 137: Özşahin ve Kaymaz, 2014; 147: Ege, 2015; 276: Uzun vd., 2015; 245).

Türkiye'deki mağaralar turizm dışında, tehlike anında sığınak olarak kullanılmakta, tarım ve hayvan ürünlerinin depolanması, kültür mantarcılığı ve sağlık (speleoterapi) alanlarında son yıllarda kullanılmaya başlanmıştır (Zeybek, 2001: 239). Yaklaşık 40.000 mağaranın olduğu tahmin edilen Türkiye'de (Ertek, 1989; 143: Sür, 1994; 16-17: Zeybek, 2001; 239: Özdemir, 2005;37: Ceylan ve Demirkaya, 2006; 201: Sever, 2008; 254: Sakıcı ve Çelik, 2017;174) bu mağaraların turizme kazandırılması için çalışmalar yapılmaktadır. Bu çalışmaların sayısı her geçen gün artmakta olup, bu durum Türkiye'deki mağara potansiyelinin zenginliğini ortaya koymaktadır. Ancak yapılan çalışmalar daha çok yerel bazda mağaraların isim ve yer olarak literatüre kazandırılması şeklinde yoğunlaşmaktadır (Kopar, 2010; 33). Bununla birlikte özellikleri ayrıntılı olarak açıklanmamış mağaraların araştırılması yerel ve bölgesel turizm faaliyetleri açısından önem arz etmektedir.

Kireç taşları mağaraların oluşumuna ortam hazırlayan en önemli kayaç türüdür. Bu kayaçların kimyasal bileşimi ve bol çatlaklı yapıları mağaraların gelişimine uygun bir ortam hazırlar. Mağaralar genellikle bir fay veya kırık hattı boyunca asit karbonatlı suların, kalsiyum karbonat (kalker) üzerindeki kimyasal eritici etkileri neticesinde oluşurlar. Bunlar başta Toros Dağları olmak üzere Güney Marmara, Batı ve Doğu Karadeniz, Doğu Anadolu Bölgesi’nin Güney ve Kuzey kesimleri ile İç Batı Anadolu'da yoğun bir oluşuma sahiptir (Nazik, 1989; 54). Son yıllarda sayısı gittikçe artan mağara araştırmalar sayesinde, Karadeniz Bölgesi'ndeki mağara potansiyelinin sanılandan çok daha fazla olduğu görülmektedir (Zeybek, 2001; 239). Bu bölgede Zonguldak, Karabük, Sinop, Kastamonu, Trabzon, Gümüşhane ve Tokat illeri mağara varlığı bakımından oldukça zengin olup, bunlardan bazıları yapılan çalışmalar neticesinde turizme kazandırılmış durumdadır.

Kastamonu, başta il arazisinin litolojik özellikleri olmak üzere, tektonik ve klimatik özelliklerinin uygun olması sebebiyle çok sayıda mağaraya sahip bulunmaktadır. Pınarbaşı ilçesindeki Ilgarini ve Mantar mağaraları, Devrekani ilçesindeki Sarpunalınca ve Sisli-Gizemli mağaraları, Şenpazar ilçesindeki Kuyluç Mağarası ve çalışmaya konu olan Cide ilçesi Kılıçlı Mağarası, Azdavay ilçesindeki Medil ve Dağlı (Kuylucu) ildeki mağaraların başlıcalarını oluşturmaktadır. Özellikle Pınarbaşı ve Azdavay ilçeleri mağaralar bakımından oldukça zengin olup, bu mağaraların yüzey araştırmaları MTA (Maden Tetkik ve Arama Enstitüsü) ve ASPEG (Anadolu Speleoloji Grubu) tarafından yapılmıştır. Bu kapsamda bu iki ilçede, Atak, Ilgarini, Medil, Buzluk, Ejder, Sipahiler, Dağlı (Kuylucu), Döngelyanı, Gökdeli gibi birçok mağaranın varlığı ortaya çıkarılmıştır. Söz konusu mağaralar, önemli turizm potansiyeline sahip olup, değerlendirilmeyi beklemektedirler.

Bu çalışmada yakın zamana kadar sadece yöre halkı tarafından bilinen ancak bilimsel olarak fazla araştırmanın yapılmadığı Medil Mağarası, coğrafi bir bakışla incelenmiştir. Medil Mağarası'nın turizm potansiyelini doğrudan konu alan ayrıntılı bir çalışma ile karşılaşılmamıştır. Bununla birlikte mağaranın 
ASPEG (Anadolu Speleoloji Grubu) ekibi tarafından incelendiği ve Medil mağarası ile ilgili "İçinde arkeolojik kalıntıları barındıran bu mă̆aralarda maalesef ăgır defineci tahribatı altındalar. Içcindeki arkeolojik kalıntılardan elde edilecek bilgiler hem bu yörede hem de genel Kastamonu bölgesindeki eski yaşam izleri hakkında bilgi verecek hem de, korunarak turizme açılması ile defineci tahribatı duracak ve öncelikle yöre insanı daha sonra turistler, bu bölge hakkında tarihsel bilgiler ile donanacaktır" şeklinde bir bilgi ve mağaranın bir haritasına yer verilmiştir (ASPEG, 2010;9). Ayrıca Kültür ve Turizm Bakanlığ1 Yatırım ve İşletmeler Genel Müdürlüğü web sitesinde mağara ile ilgili bir tanıtıcı bilgi bulunmaktadır. Sakıcı ve Çelik (2017) ise Medil mağarasının yeri ve kültürel özelliği ile ilgili kısa bir bilgi vermiş, mağaranın bazı hastalıklara iyi geldiğinden bahsetmiştir. Doğal özellikler bakımından önemli bir potansiyele sahip olan Medil Mağarası, arkeolojik olarak da önemli bir alan özelliği göstermektedir. Bu çalışmada ise Medil Mağarası'nın oluşumunun ve özelliklerinin tanıtımının yapılması, çevresindeki diğer çekiciliklerle birlikte turizm potansiyelinin değerlendirilmesi, böylelikle hem yöre hem de bölge ekonomisine katkı sağlanması amaçlanmaktadır.

Bu çalışma hazırlanırken arazi incelemeleri dışında, 1/25.000 ölçekli E30d2, E30d3, E30c1, E30c4 paftaları ve 1/100.000 ölçekli E30 pafta numaralı topografya haritalarından, 1/100.000 ölçekli D30-E30 jeoloji haritalarından, ekli literatürden ve yöredeki Kastamonu ve Azdavay meteoroloji istasyonlarının verilerinden yararlanılmıştır. Ayrıca, mağara ve yakın çevresinden numune olarak alınan kireçtaşlarının $\mathrm{CaCO}_{3}$ içerikleri Maden Tetkik ve Arama Genel Müdürlüğü'ne gönderilmiş kireçtaşlarının içeriği incelenmiş ve mağaranın oluşumundaki etkileri belirlenmeye çalışılmıştır. Bu amaçla 2018 yaz aylarında yapılan arazi çalışmaları sırasında mağara içerisinden ve yakın çevresinden 4 adet kireçtaşı numunesi incelenmek üzere alınmıştır.

Arazi çalışmaları esnasında mağaranın yeri, metrik ve morfolojik özellikleri belirlenmiştir. Ayrıca yakın çevre şartları incelenmiş, ulaşım ve arazi kullanımıyla ilgili bilgiler derlenmiş ve fotoğraflama işlemleri gerçekleştirilmiştir. Büro çalışmaları sırasında araziden ve literatürden derlenen bilgiler Coğrafi Bilgi Sistemleri (CBS) teknikleri kullanılarak haritalanmıştır. CBS analizlerinde ArcGIS10 yazılımı tercih edilmiş, $15 \mathrm{~m}$ yersel çözünürlüğe sahip ASTER uydu görüntülerinden spatial analiz modellerinde yüzey sorgulama (raster surface) analizi yapılmış ve bunun sonucunda hillshade üretilmiştir. $\mathrm{Bu}$ analizler sonucunda sahaya yönelik yükseklik kademeleri oluşturulmuş hillshade ile desteklenerek üç boyutlu hale getirilmiştir.

Ayrıca MTA tarafından hazırlanmış 1/100.000 ölçekli Türkiye Jeoloji Haritası'nın ilgili paftaları ile arazi gözlemleri birleştirilerek inceleme sahasının jeoloji haritası üretilmiştir Arazi çalışmaları sırasında koordinat ve yükseklik ölçümleri "Magellan Triton 500" GPS ile yapılmış ve ardından Google Earth programına işlenmiştir. Eğim, yükseklik ve mesafe ölçümleri ise "Leica DISTO D8" lazer metresi ile yapılmıştır. Çalışmada kullanılan yol uzunlukları ise Google maps üzerinden hesaplanmıştır.

\section{Mağaranın Yeri ve Doğal Çevre Özellikleri}

Medil Mağarası, Kuzey Anadolu Dağlık Kuşağı içerisinde yer alan Küre Dağlık Kütlesinin Azdavay-Pınarbaşı arasında bulunan Kaldırım Dağı'nın güneybatı yamacında bulunmaktadır. Hidrografik olarak Batı Karadeniz Bölümü'nün önemli akarsularından birisi olan Devrekani Çayı'nın su toplama havzası içerisinde bulunan mağara, bu akarsuyun açmış olduğu Çatak Kanyonu'nun doğu yamacında bulunmaktadır (Şekil 1). İdari olarak Batı Karadeniz Bölümü’nde Kastamonu iline bağlı Azdavay ilçesinin Karakuşlu köyüne bağlı Ayvat mahallesi sınırları içerisinde yer almaktadır. Kastamonu şehrinin yaklaşık $95 \mathrm{~km}$ kuzeybatısında yer alan mağara, Azdavay ilçe merkezine yaklaşık $7 \mathrm{~km}$ uzaklıktadır. Azdavay ilçe merkezinde mağara yolunu gösteren bir tabela bulunmaktadır (Foto 1). Azdavay’1 Pınarbaşı ilçesine bağlayan karayolunun 3. km'sinde asfalt yoldan ayrılarak Karakuşlu köyü yol ayrımın takip etmek gerekmektedir. $\mathrm{Bu}$ yol ayırımından sonra Karakuşlu köyünün girişindeki Küre Dağları Milli Park1 tabelasını geçip (Foto 2) yaklaşık $2 \mathrm{~km}$ Ayvat mahallesine doğru gidildikten sonra Medil mağarası tabelasının olduğu yerden tekrar batıya doğru stabilize yola doğru devam edilmektedir (Foto 3). Buradan itibaren Hümatepenin güney yamacı boyunca açılmış yoldan $1 \mathrm{~km}$ gidildikten sonra Küre Dağları Milli Parkı tabelasının olduğu yere gelinmektedir (Foto 4). Buraya kadar araç ile ulaşımın mümkün olduğu Medil 
mağarasına tabelanın bulunduğu yerden yaklaşık $1 \mathrm{~km}$ 'lik orman içinde kuzeybatı yönünde patika bir yoldan yürüyerek ulaşılmaktadır.



Şekil 1. Medil mağarası ve yakın çevresinin lokasyon haritası.

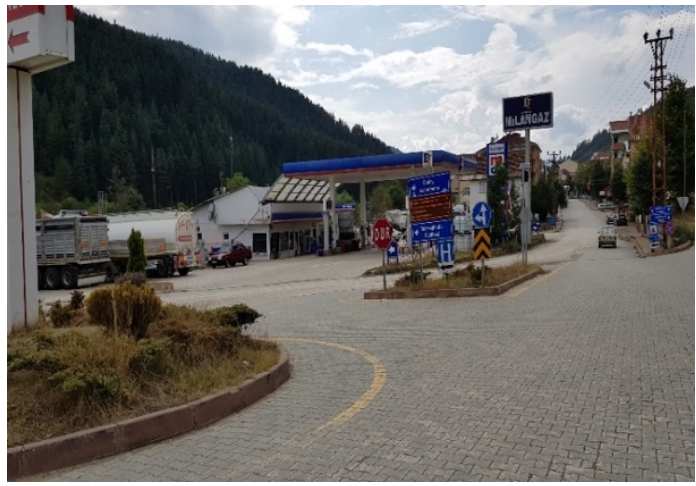

Foto 1. Azdavay ilçe merkezinin girişinde Medil mağarasını gösteren tabela.



Foto 3. Ayvat mahallesi yolu üzerinde Medil mağarası ayrımını gösteren tabela.

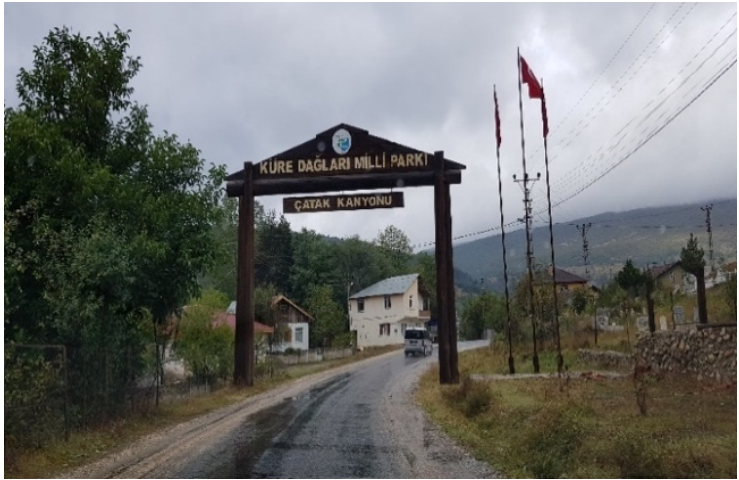

Foto 2. Karakuşlu köyü girişindeki Küre Dağları Milli Parkı tabelası.

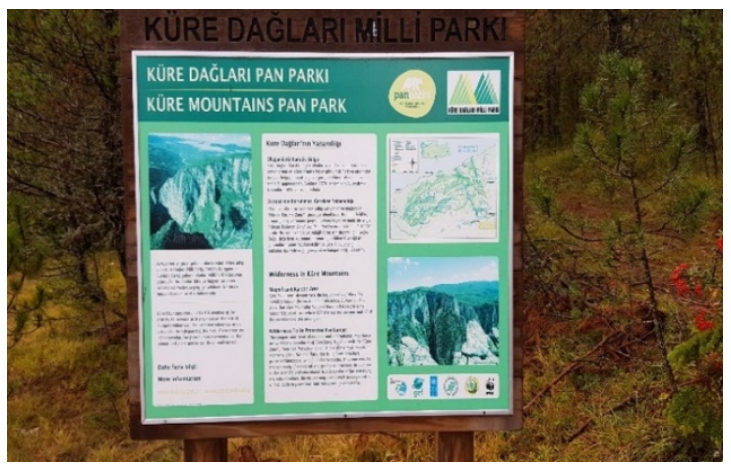

Foto 4. Medil mağarasının $1 \mathrm{~km}$ güneybatısında bulunan Küre Dağları Milli Parkı tabelası. 
Devrekâni Çayı'nın oluşturduğu Çatak Kanyonu'nun doğu yamacında yer alan Medil mağarası, vadi tabanından yaklaşık $100 \mathrm{~m}$ kadar yüksekte yer almaktadır. Mağaranın pafta ve kadastro numarası, "Kastamonu E30-d2/1" ve koordinatları "X:51982, Y:46096” olarak belirlenmiştir. Mağaranın giriş kısmının deniz seviyesinden yüksekliği Garmin Gps ile 1046 m ölçülmüştür.

Araştırma sahası ve yakın çevresinde yapılmış olan araştırmalarla, Medil mağarası ve yakın çevresinin jeolojik özellikleri büyük kısmı ile ortaya konulmuştur. Maden Tetkik ve Arama Genel Müdürlüğü'nün 1/100.000 ölçekli Kastamonu D30-E30 paftalarından yararlanılarak Medil mağarası ve çevresinin jeoloji haritası hazırlanmıştır (Şekil 2). Mağara ve yakın çevresinde aflörman veren en eski temel kayaçları Karbonifer dönemine ait Karadon formasyonu (Cka) oluşturmaktadır. Bu birim çakıltaşı, kumtaşı, kiltaşı, şeyl ve diyotomitten oluşmaktadır (Uğuz ve Sevin, 2010;10). Medil mağarasının doğusunda Azdavay ilçe merkezinin batısında geniş bir dağılışa sahip bu birim, Kocaoğullar mahallesi ile Bakırcı mahalleleri arasında yüzeylenmiştir. Permiyen-Triyas dönemi kayaçlarını ise Çakraz formasyonu (PTç) oluşturmaktadır (Akyol ve diğ., 1974;12). Kızılımsı alaca renkte çakıltaşı, şeyl, çamurtaşı ve kumtaşından oluşan bu birim Azdavay ilçesinin batısında oldukça yaygındır. Araştırma sahasında Mesozoik'e ait kayaçların ilk grubunu Akgöl formasyonu (Tja) oluşturmaktadır. Siyah renkli kayrak, fillat, şeyl ve kumtaşından oluşan bu birime Ketin ve Gümüş (1962) "Akgöl” adını vermiştir. Azdavay ilçe merkezinin güneyindeki Karahalılar köyü çevresinde yaygın olan bu birimin, Yılmaz (1980) araştırma sahasına yakın olan Devrekani yöresinde yaptığı çalışmalarda yaklaşık 1000 m kalınlığa sahip olduğunu ifade etmektedir. $\mathrm{Bu}$ birimin bir diğer özelliği, içinde yaygın olarak kireçtaşı ve mermer bloklarının gözlemlenmesidir. Kireçtaşı blokları gri renkli, orta-kalın tabakalı, yer yer masif özelliktedir. Mermer blokları ise orta-kalın tabakalı, yer yer masif görünümlü, açık gri-kirli beyaz renkli olup, kalsit-mermer, kalsit-dolomit-mermer, dolomit-mermer biçimlerine sahip oldukları dikkati çekmektedir (Uğuz ve Sevin, 2010;9). Çalışma sahasındaki ikinci zamana ait kayaçlardan bir diğerini ise Alt-Orta Jura dönemine ait örtü formasyonu olan Bürnük formasyonu (Jb) oluşturur. Çakıltaşı, kumtaşı ve çamurtaşı ardalanmasından oluşan bu birim Azdavay ilçe merkezi çevresi ile Medil mağarasının doğusundaki Örencik ve Karakuşlu köyleri ile Ayvat ve Kırpaköy mahalleleri çevresinde yüzeylenmişlerdir. Bu formasyonun kalınlığı ortalama 300-400 m civarındadır (Yılmaz ve Tüysüz, 1984;18).

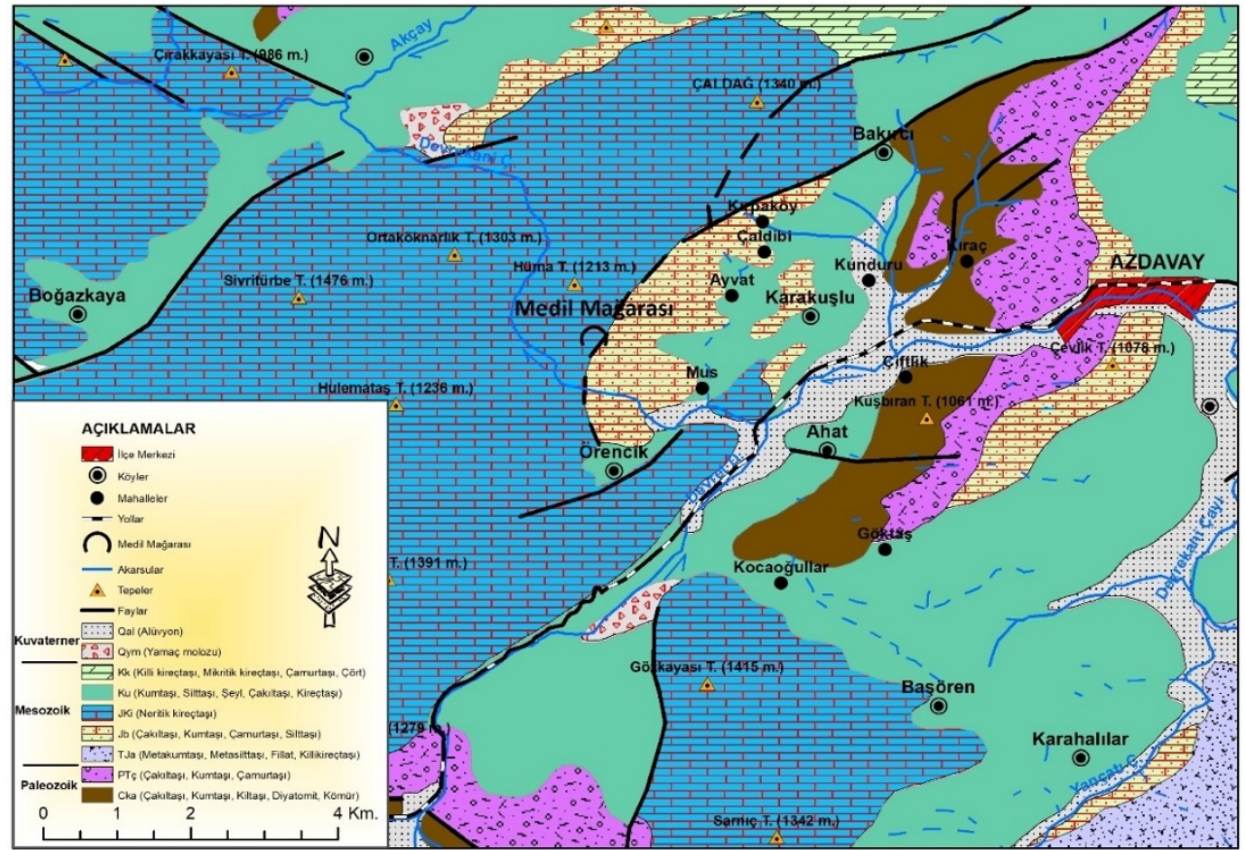

Şekil 2: Mağara ve yakın çevresinin jeoloji haritası MTA'nın Türkiye Jeoloji Haritaları Kastamonu-E30 ve D-30 Paftalarından (1/100.000 Ölçekli) yararlanılarak hazırlanmıştır. 
İnceleme alanında en geniş yayılışa sahip olan ve Medil mağarasının da içinde oluştuğu İnaltı formasyonu (JKi) Üst Jura-Alt Kretase yaşlıdır. Neritik-şelf özellikli kireçtaşlarından oluşan bu birim adını Ayancık ilçesinin yaklaşı $24 \mathrm{~km}$ güneyinde yer alan İnaltı köyünden almaktadır (Ketin ve Gümüş, 1963;12). Altta beyaz, açı gri, gri renkli, genellikle kalın tabakalı, yer yer iri gastropod kavkıll, yer yer mercanlı ve algli, bol kalsit damarlı rekristalize kireçtaşları bu formasyonda yaygın olarak gözlemlenir. Üste doğru gri, koyu gri renkli, çoğunlukla orta tabakalı kireçtaşları arasında ince şeyl katkıları gözlemlenmeye başlanır. Kil oranının arttığı kimi düzeylerde kireçtaşı tabakaları yumrulu bir görünüm kazanır. Bu yumrulu görünümlü tabakalar üst bölümlerde orta-kalın tabakalı, intraformasyonal özellikli çakıllı düzeylerle ardalanır. Bu intraformasyonal ve yumrulu kireçtaşı ardalanması kalın tabakalı, kırmızımsı kül renkli, kırıntılı görünümlü kireçtaşları ile devam eder (Uğuz ve Sevin, 2010;13). İnaltı formasyonu alttan Bürnük Formasyonu ile geçişlidir. Birçok yerde bölgenin temel kayaları üzerine geldiği gözlemlenmekte olup, Yılmaz (1980) bu birimde $480 \mathrm{~m}$ kalınlık ölçmüştür. Mağaranın da içinde geliştiği bu kireçtaşları, aynı zamanda bol kırıklı ve çatlaklıdırlar. Bu durum, mağara içerisinde takip edilmekte olup, mağaranın gelişiminde kuzeydoğu-güneybatı yönünde uzanan fayların da önemli etkisi bulunmaktadır. Mağara ağzında aynı doğrultulu bir çatlak sistemi belirgin olarak gözlenmekte olup, söz konusu zayıf zon mağaranın gelişim doğrultusunu da belirlemiştir.

Kretase dönemine ait örtü kayaçları birimini oluşturan Ulus formasyonu (Ku) Azdavay ilçe merkezi çevresi ve Medil mağarasının kuzeybatısında yayılış göstermektedir (Şekil 2). Bu birim, kumtaşı, silttaşı, şeyl ve az çakıldan oluşan bir yapıya sahiptir (Akyol ve diğ. 1974; 5). Birimi oluşturan kayaçlar kirli sarı, sarımsı-kahverengimsi gri, gri renkli, orta-kalın tabakalı kumtaşı ile ince tabakalı gri renkli silttaşı şeyl ardalanması biçiminde bir yapıya sahiptir. Bu birimi oluşturan kayaçlar bir denizaltı yelpaze çökeli olarak tespit edilmiştir (Uğuz ve Sevin, 2010;9).

Araştırma sahasında Azdavay kuzeyinde görülen bir diğer birimi Kapanboğazı formasyonu (Kk) oluşturmaktadır. Killi kireçtaşı, mikritik kireçtaşı, çörtlü kireçtaşı ardalanmasından oluşmaktadır. Yaklaşık $100 \mathrm{~m}$ kalınlığa sahip bu formasyon ince-orta tabakalı, düzgün tabakalanmalı, genellikle kırmızımsı bordo ve kiremit renklidir (Uğuz ve Sevin, 2010;16).

Kuaterner araştırma sahasında yamaç molozu ve alüvyonlar ile temsil edilir. Tutturulmamış veya az tutturulmuş blok ve çakııllardan oluşan yamaç molazları Gökkayası tepenin $(1415 \mathrm{~m})$ kuzey yamaçlarının etekleri ile Devrekani Çayı'nın oluşturduğu Çatak Kanyonu'nun çıkışındaki eğimli vadi yamacı altında görülmektedir. Alüvyonlara ise Karahalılar köyü, Azdavay ilçe merkezi ve Mus mahallesi arasında menderesli ve örgülü bir akış gösteren Devrekani Çayı'nın vadi tabanında rastlanmaktadır. Çakıl, kum, silt ve çamur birikintilerinden oluşan alüvyonlar üzerinde yöre halkı tarımsal faaliyetlerini yürütmektedir.

Medil mağarasının bulunduğu saha, Devrekani Çayı ve onun yan kolları tarafından sık ve derin bir şekilde yarılmıştır (Şekil 3). Aynı sahada yamaç eğim değerleri de oldukça fazla olup yer yer \%60'1 bulmaktadır. Bu yarılmaya bağlı olarak mağaranın hemen batısında Çatak ve kuzeyinde Valla Kanyonları gibi bağıl yarılmanın yer yer 800-900 m'yi bulduğu derin vadiler oluşmuştur. Mağaranın da bulunduğu Devrekani Çayı havzasının bu bölümünde yaklaşık $1000 \mathrm{~m}$ ler civarında bir aşııım yüzeyi geliş̧şştir (Kurter, 1982:18). Ancak güneyden kuzeye doğru nispeten eğimli olan bu aşınım yüzeyinin üzerinde yükseltileri 1400 m'ye varan zirveler bulunmaktadır. Medil mağarası ve yakın çevresinde morfolojik üniteler eskiden yeniye ve güneyden kuzeye doğru Miyosen döneminde oluşmuş peneplen, Üst MiyosenPliyosen pedimenti, sıyrılmış (eksüme) yüzeyler, akarsu şekilleri ve vadi tabanları şeklinde sıralanmaktadır (Keçer, vd. 2001). Giriş yüksekliği yaklaşık $1046 \mathrm{~m}$ olan Medil mağarasının çevresindeki en önemli yükseltileri Gözkayası tepe $(1415 \mathrm{~m})$, Katırörenci tepe $(1391 \mathrm{~m})$, Çaldağ $(1340 \mathrm{~m})$, Ortaköknarlık tepe $(1303 \mathrm{~m})$, Hulemataş tepe $(1236 \mathrm{~m})$ ve mağaranın güney yamacında oluştuğu Hüma tepe $(1213 \mathrm{~m})$ oluşturmaktadır (Şekil 3). 




Şekil 3. Medil Mağarası ve yakın çevresinin topoğrafya haritası.

Medil mağarası'nın da bulunduğu bu yörenin iklim özelliklerinin ortaya konulmasında Kastamonu (800 m) ve Azdavay ( $825 \mathrm{~m}$ ) meteoroloji istasyonlarının rasat verilerinden faydalanılmıştır (MGM, 2018). $\mathrm{Bu}$ verilere bakıldığında yıllık ortalama sıcaklık değeri mağaranın güneyinde bulunan Kastamonu'da 9,8 ${ }^{\circ} \mathrm{C}$ iken, mağaraya $7 \mathrm{~km}$ uzaklıktaki Azdavay'da 8,3 ${ }^{\circ} \mathrm{C}$ 'dir. Her iki istasyonda da aylık ortalama sıcaklıkların seyrine göre sıcaklığın en düşük olduğu ay Ocak ayıdır. Ocak ayı ortalaması Kastamonu'da $1,1{ }^{\circ} \mathrm{C}$, Azdavay'da ise $-1,2{ }^{\circ} \mathrm{C}$ 'dir. Buna karşılık aylık ortalama sıcaklıklar da yılın en sıcak ayını her iki istasyonda da temmuz ayı oluşturmaktadır. Bu ayda Kastamonu'da ortalama sıcaklıklar $20,3{ }^{\circ} \mathrm{C}$ iken Azdavay'da $17,6{ }^{\circ} \mathrm{C}$ olarak gerçekleşmektedir (Tablo 1, Şekil 4, 5).

Tablo 1. Kastamonu ve Azdavay meteoroloji istasyonlarına ait sıcaklık $\left({ }^{\circ} \mathrm{C}\right)$ ve yağış $(\mathrm{mm})$ verileri.

\begin{tabular}{|c|c|c|c|c|c|c|c|c|c|c|c|c|c|c|}
\hline İstasyonlar & & O & $\mathbf{S}$ & $\mathbf{M}$ & $\mathbf{N}$ & $\mathbf{M}$ & H & $\mathbf{T}$ & $\mathbf{A}$ & $\mathbf{E}$ & Ek & $\mathbf{K}$ & $\mathbf{A}$ & Yıllık \\
\hline \multirow{2}{*}{ 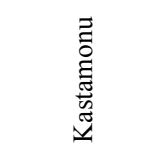 } & $\begin{array}{l}\text { Ortalama Sicaklık } \\
\left({ }^{\circ} \mathrm{C}\right)\end{array}$ & $-1,1$ & 0,7 & 4,3 & 9,5 & 14,2 & 17,6 & 20,3 & 20,0 & 15,7 & 10,7 & 5,1 & 0,8 & 9,8 \\
\hline & $\begin{array}{l}\text { Aylık Toplam Yağış } \\
\text { Miktarı } \\
\text { Ortalaması }(\mathrm{mm})\end{array}$ & 29,9 & 27,0 & 34,5 & 51,8 & 74,1 & 71,4 & 31,8 & 31,2 & 30,1 & 35,3 & 29,1 & 33,8 & 480,0 \\
\hline \multirow{2}{*}{ 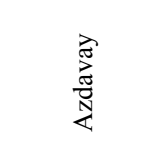 } & $\begin{array}{l}\text { Ortalama Sicaklık } \\
\left({ }^{\circ} \mathrm{C}\right)\end{array}$ & $-1,2$ & $-0,4$ & 3,1 & 7,8 & 11,6 & 15,2 & 17,6 & 17,5 & 13,3 & 9,6 & 4,3 & 0,8 & 8,3 \\
\hline & $\begin{array}{l}\text { Aylık Toplam Yăğıs } \\
\text { Miktarı } \\
\text { Ortalaması (mm) }\end{array}$ & 55,8 & 40,2 & 36,3 & 57,7 & 61,4 & 66,6 & 29,6 & 23,5 & 33,3 & 71,3 & 57,3 & 65,3 & 598,3 \\
\hline
\end{tabular}

Kaynak: DMIGM (2018) rasat verileri.

Medil mağarasına yaklaşık kuş uçuşu 4 km mesafede bulunan Azdavay'da yıllık ortalama yağış miktarı 598,3 mm buna karşılık mağarayı yaklaşık kuş uçuşu $50 \mathrm{~km}$ mesafede olan Kastamonu'da 480 mm'ye düşmektedir. Batı Karadeniz Bölümü'nün iç kısımlarında Kuzey Anadolu Dağlık Kuşağı'nda yer alan her iki istasyona ait yıllık ortalama sıcaklık ve yağış değerlerindeki bu farklılı̆̆ın topoğrafik yapı ve enlem etkisinden kaynaklandığı söylenebilir. Azdavay meteoroloji istasyonunun sıcaklık ve yağış değerleri 
her mevsim yağışı Karadeniz ikliminin özelliklerini gösterirken, daha güneyde bulunan Kastamonu meteoroloji istasyonunun bu değerleri yörede karasallığın ağır bastığı bir iklim tipinin etkili olduğunu göstermektedir.

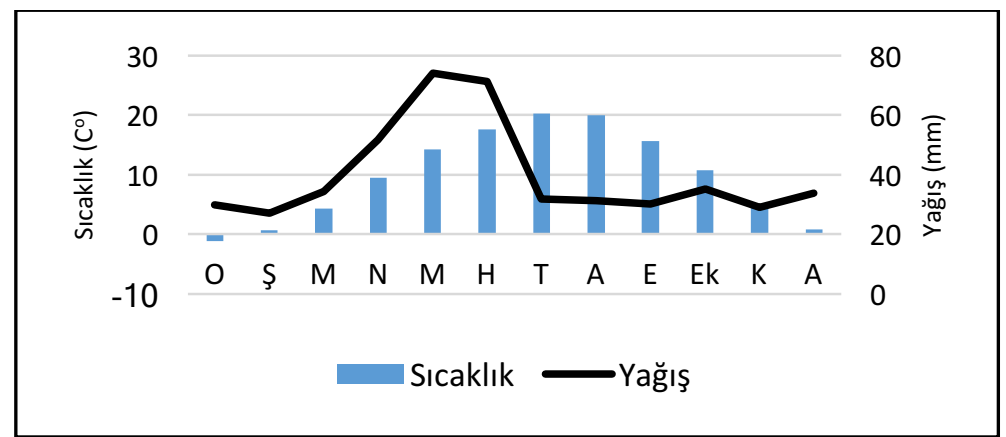

Şekil 4. Kastamonu'nun yıllık ortalama sıcaklık ve yağı̧s grafiği.

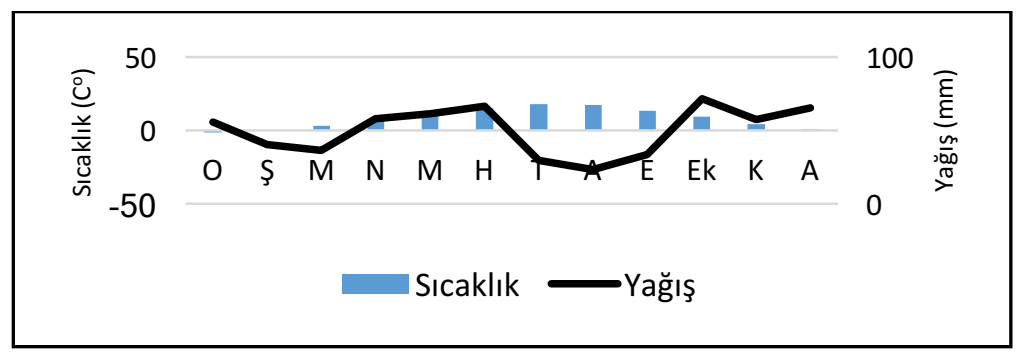

Şekil 5. Azdavay'ın yıllık ortalama sıcaklık ve yağış grafiği.

Nitekim Kastamonu'nun iklimi ile ilgili yaptığı çalışmada Kurter (1971) bu duruma dikkati çekmiş ve Kastamonu'nun iklim özellikleri olarak iç kısımlara daha fazla benzerlik gösterdiğini söylemektedir. Yaz ve kış mevsimleri arasındaki sıcaklık farkının, gece ve gündüz sıcaklıkları arasındaki farkın, kıyıdaki istasyonlara göre yağış azlığının, uzun yaz kuraklığının ve kar yağış süresinin uzunluğu gibi bazı özelliklerin karasal iklime daha fazla yakın olduğunu ifade etmektedir. Ayrıca Kastamonu ve özellikle kuzeyindeki ilçelerinde iklim özelliklerinin tayininde topoğrafik yapının geniş ölçüde belirleyici olduğunu, Karadeniz dağlık kuşağının güneyindeki havza karakterli alanlarda İç Anadolu karasal ikliminin etkili olduğunu ifade ederken, kuzeye doğru daha az sıcaklık ortalamaları ve daha nemli yağış özellikleri ile Karadeniz ikliminin etkilerinin görüldüğünü ifade etmektedir (Kurter, 1971;194). Medil mağarasına oldukça yakın olan Azdavay meteoroloji istasyonu rasat verilerine göre yörede yılın her ayı yağışlı geçmektedir. Ancak özellikle nisan-haziran ve ekim-ocak ayları arasında yağışın çak daha fazla düştüğü görülmektedir. Yağışların aylık ortalama değerlerine bakıldığında en fazla yağışın 71,3 mm ile ekim ayında, en az yağıșın $23,5 \mathrm{~mm}$ ile ağustos ayında gerçekleștiği görülür. Buna göre mağara ve çevresinde yağıșların nispeten düzenli bir gidişat gösterdiğini söylemek mümkündür. Ancak ilkbahar başındaki mart ayında ve yazın temmuz ve ağustos aylarında yağışların azaldığı uzun yıllık ortalama verilerden anlaşılmaktadır. Yağışların büyük bölümü yağmur şeklinde gerçekleşirken, yılın sadece 33,3 gününde kar yağış1 gerçekleşmektedir. İlkbahar mevsimindeki sıcaklık artıșına bağlı gerçekleșen kar örtüsünün hızla erimesi ve artan yağışlar, litolojinin de uygun olduğu alanlarda karstlaşmayı destekler nitelik taşımaktadır.

İnceleme sahasının sularını Devrekani Çayı drene etmektedir. Bu akarsu Devrekani ilçesinin kuzeyindeki dağlık alandan batıya doğru bir akış göstererek Seydiler ilçesi çevresindeki Bük çayı, İncesi çayı, Halat çayı gibi yan kolları alarak akışına devam eder. Devrekani Çayı, Ağlı ve Azdavay çevresindeki Çalça deresi, Sarpun deresi, Yumacık deresi, Toka deresi, Akçay deresi ve Kanlıdere gibi yan kollarında katılmasıyla Pınarbaşı ilçesine ulaşır. Buradan itibaren Kuzey Anadolu dağlarının oluşturduğu sıradağlar içerisinde dar ve derin vadiler açarak akış gösteren Devrekani Çayı Çatak ve Valla olmak üzere iki önemli kanyon vadinin oluşumunu sağlamıştır (Foto 5). Bu kanyon vadileri aşan akarsu Cide ilçe merkezinin batısından denize dökülmektedir. 



Foto 5. Medil mağarasına yaklaşık 4 km mesafede bulunan Çatak Kanyonu seyir terasının giriş ve cam teras bölümü.

Devrekani Çayı Batı Karadeniz Havzası'nda yaklaşık $2.322 \mathrm{~km}^{2}$ lik bir su toplama alanına sahiptir. Devrekani Çayı ve yan kollarından oluşan bu açık havzanın su potansiyeli 400 milyon $\mathrm{m}^{3}$ civarındadır (Öztürk ve diğ., 2012; 15). Devrekani Çayı havzası kuzeyde Karadeniz, doğu ve güneydoğuda Gökırmak, güneyde Araç çayı, batıda ise Bartın çayı havzaları tarafından sınırlandırılmaktadır. Oldukça geniş bir havzaya sahip olan Devrekani çayı, Aydavay ilçesinin dışında Devrekani, Daday, Ağlı, Seydiler, Pınarbaşı ve Cide ilçelerinin topraklarından geçerek Karadeniz'e sularını boşaltmaktadır. İnceleme sahasındaki akarsuların akım rejimlerini ortaya koymak amacıyla DSİnin Devrekani Çayı üzerinde kurmuş olduğu akım gözlem istasyonlarının rasat verileri tablo 2'de verilmiştir.

Tablo 2. Devrekani Çayı üzerindeki Cide ve Azdavay istasyonlarının yıllık akım değerleri ( $\left.\mathrm{m}^{3} / \mathrm{sn}\right)$.

\begin{tabular}{|c|c|c|c|c|c|c|c|c|c|c|c|c|}
\hline $\begin{array}{l}\text { İstasyon } \\
\text { Adı }\end{array}$ & Ek & $\mathbf{K}$ & $\mathbf{A}$ & $\mathbf{O}$ & Ş & M & $\mathbf{N}$ & M & $\mathbf{H}$ & $\mathbf{T}$ & $\mathbf{A}$ & $\mathbf{E}$ \\
\hline $\begin{array}{l}\text { Devrekâni } \\
\text { Çayı } \\
\text { (Cide) }\end{array}$ & 9,751 & 20,314 & 26,119 & 36,939 & 43,594 & 58,276 & 44,602 & 22,226 & 17,114 & 6,498 & 4,398 & 3,995 \\
\hline $\begin{array}{l}\text { Devrekâni } \\
\text { Çayı } \\
\text { (Azdavay) }\end{array}$ & 1,308 & 2,635 & 5,861 & 7,510 & 11,370 & 19,012 & 13,756 & 9,724 & 5,600 & 2,129 & 1,060 & 0,914 \\
\hline
\end{tabular}

Kaynak: http://rasatlar.dsi.gov.tr/ (Erişim tarihi 17.11.2018).

Tablo 2 incelendiğinde, Devrekâni Çayı üzerindeki Cide ve Azdavay istasyonlarına ait aylık akım değerlerinin akarsuyun kaynak kısmına yakın bölümü ile ağız kısmı arasında belirgin farklılık gösterdiği gözlemlenmektedir. Bu durum hem iç kesimlerdeki yağış azlığından hem de ağız kısmına doğru ana akarsuya katılan yan kolların fazlalığından kaynaklanmaktadır (Şekil 6 ve 7). Ancak her iki istasyon için de şubat ayından nisan ayına kadar bol akımlı bir devrenin varlığı ve diğer aylara karşılık gelen bir akım azlığından söz edilebilir. Bununla birlikte her iki istasyonda da maksimum ve minimum akımlar arasındaki fark oldukça belirgindir. Bu durum kar erimelerinin ve yağış miktarının etkisi ile ortaya çıkmaktadır. Her iki istasyon içinde mart maksimumuna karşılık eylül minimumu ayırt edilmektedir. Bu durum, iklim kısmında da değinilen ve araştırma sahasının güneyindeki yağış azlığı ile paralellik göstermektedir.

Araştırma sahasındaki akarsuların akış şartları üzerinde etkili olan temel faktörlerden biri iklimdir. İklimle ilgili özellikle yağışın şekli, miktarı ve sıcaklık rejimi hidrografik özelliklerin belirlenmesinde oldukça etkili olmaktadır. Saha içerisindeki akarsular genellikle kaynak suları ile beslenmeleri ve yıl boyunca su taşımalarına rağmen, yağışların fazla olduğu ilkbahar aylarında ve karların erime döneminde akımlarının nispeten arttı̆̆ı gözlemlenmektedir. Bununla birlikte inceleme sahasının akış şartları iklim özellikleri yanında, ana kaya, eğim ve bitki örtüsü ile de yakından ilişkilidir. Bitki örtüsünün yoğun olduğu bu akarsuların su toplama havzalarında biriken sular akarsuların yıl boyu sürekli akışa sahip olmalarını sağlamaktadır. Ayrıca yağış miktarının fazla olması ve ana kayaya bağlı olarak yüzeyden akış gösteren suların kireçtaşlarının yarık ve çatlaklarından sızarak yeraltı sularını oluşturduğu görülür. Karstlaşmaya 
önemli etkisi olan bu sular vadi tabanları veya yamaçlardan karstik kaynak olarak tekrar yüzeye çıkmaktadır.

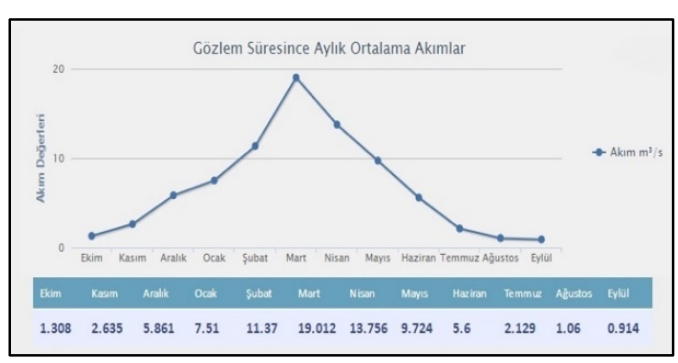

Şekil 6: Devrekani Çayı üzerindeki Azdavay istasyonunun aylık akım değerleri.

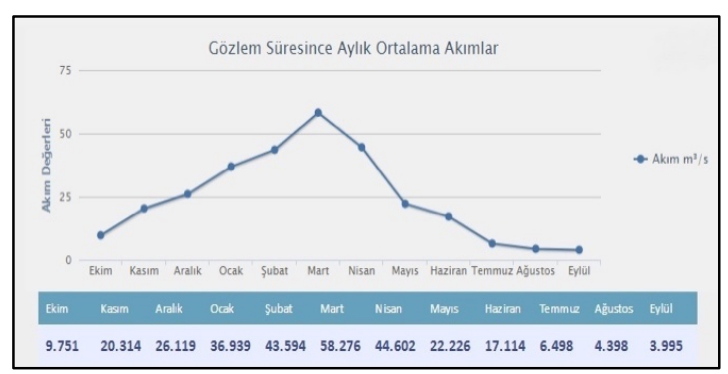

Şekil 7: Devrekani Çayı üzerindeki Cide istasyonunun aylık akım değerleri.

Medil mağarası, Küre Dağları Milli Parkı "Mutlak Koruma Zonu” içerisinde yer aldığı için koruma altındadır. Kastamonu ve Bartın illerinin sınırları içerisinde bulunan Milli Park Cide, Şenpazar, Azdavay, Pınarbaşı, Ulus, Amasra ve Kurucaşile ilçeleri ile çevrilidir. 07.07.2000 tarihinde Milli Park olarak ilan edilen Küre Dağları 37.000 hektarlık "Mutlak Koruma Zonu" ile kırsal yerleşim birimlerini içine alan 80.000 hektarlık “Tampon Zon” olarak ayrılmıştır. Küre Dağları Milli Parkı tampon zonla birlikte 117.000 hektarlık bir alana sahiptir (DOPEM, 2011). Medil mağarası, Milli Parkın güneybatı bölümünde yer almaktadır. Azdavay yöresi bütünü ile orman alanı içerisinde yer almaktadır. Ayrıca orman altı örtüsü de yağışların fazlalığına bağlı olarak son derece zengindir. Ormanlar sert kışlara dayanıklı ve daha çok nemcil karakterdeki ağaçlardan oluşmaktadır. Öksin flora bölgesinin (Karadeniz Alanı) içerisinde yer alan Azdavay ve çevresini Atalay (1983) Kuzey Anadolu yarı nemli-kışa dayanıklı göknar, kayın, sarıçam orman alanı olarak ifade etmektedir. Göknar, kayın ve sarıçam gibi elemanların ağırlıklı olduğu bu orman örtüsü yerleşim birimlerine yakın alanlarda kısmen tahribata uğramıştır. Ayrıca bu tahribat mermer ocaklarının açılması ile de katlanarak artmaktadır (Foto 6).
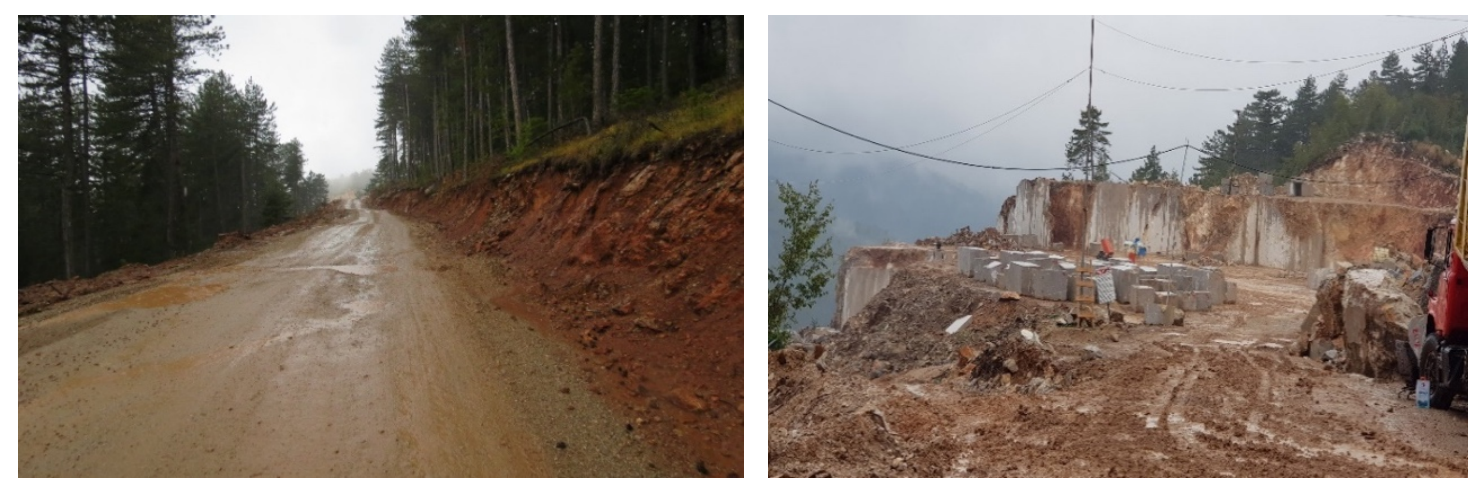

Foto 6. Medil mağarası yakınındaki Örencik köyü yakınlarında sarıçam ormanları içerisinde mermer çıkarmak için açılan yol ve mermer ocağı.

Yöredeki bitki örtüsünün yoğunluğu karstlaşma ve mağara gelişimi üzerinde de etkili olmuştur. Yağış miktarının nispeten fazla olduğu inceleme alanında yağmur ve eriyen kar suları içerisine nüfuz eden $\mathrm{CO}_{2}$ ve organik asitler, toprak örtüsünden geçmekte, anakaya ile temas ederek çözünmesini hızlandırmaktadır. Öte yandan geçmişte asitçe zengin sular yeraltı akarsularını besleyerek, mağara galerinin gelişimine de katkı sağlamış olmalıdır.

Daha çok yüksek alanlarda yayılış gösteren orman formasyonunu oluşturan elemanlardan göknar (Abies nordmanniana subsp.), kayın (Fagus sp.) ve sarıçam (Pinus sylvestris) türler yükselti ve bakıya bağlı olarak bazen saf ormanlar halinde bazen ise karışık ormanlar şeklinde yayılmıştır. Bu hâkim türlere eşlik eden diğer ağaç türleri ise akçaağaç (Acer campestre), çınar yapraklı akçaağaç (Acer platanoides), kestane (Castanea sp.), adi gürgen (Carpinus betulus) gibi türlerdir. Devrekâni çayı havzası yağış fazlalığının 
etkisine bağlı olarak ormanaltı florası bakımından da oldukça zengindir. Eğrelti otu (Pteridium aquilinum), mor çiçekli ormangülü (Rhododendron ponticum), beyaz hindiba (Cichorium inthybus.), keçi furtılı (Cytisus pygmaeus) orman altı florasının oldukça yaygın türleridir. Sahada yer yer ormanların tahrip edildiği alanlarda ise, yabani fındık (Corylus sp.), adi alıç (Crataegus monogyna), alıç (Crataegus sp.), ağızlık çalısı (Staphylea pinnata), kuşburnu (Rosa canina) gibi türler bulunmaktadır. Bazı korunaklı alanlarda tür çeşitliliği daha artmakta adi şimşir (Buxus sempervirens), yabani findık (Corylus sp.), adi alıç (Crataegus monogyna), alıç (Crataegus sp.), kayın (Fagus sp.), dişbudak (Fraxinus excelsior subsp. Excelsior), kurtbağrı (Ligustrum vulgare), yabani elma (Malus sylvestris subsp. Sylvestris), muşmula (Mespilus germanica), titrek kavak (Populus tremula), erik (Prunus domestica), karayemiş (Prunus laurocerasus officinalis), kuşburnu (Rosa canina), söğüt (Salix sp.) gibi türler yaygın olarak görülmektedir.

\section{Medil Mağarasının Oluşumu ve Özellikleri}

\subsection{Mağaranın Olușumu}

Medil mağarasının da bulunduğu Azdavay yöresinde Pleistosen 'deki birbirini takip eden nemli ve kurak devrelere bağlı olarak Devrekani Çayı'nın aktivitesinin arttığı söylenebilir. Akış gösterdiği havzayı gittikçe genişleten Devrekani Çayı'nın bu faaliyeti deniz seviyesindeki değişikliklere bağlı olarak farklılık göstermiştir. Bu dönem ayrıca yörede geniş alanlara yayılan kireçtaşları üzerinde karstik depresyonların oluşmasında da etkili olmuştur (Kurter, 1982;213). Devrekani Çayı'nın kolay çözülen Mesozoik dönemine ait serilerin yaygın olduğu depresyonları hızla aşındırması ve vadisini derinleştirmeye başlaması Azdavay yöresinde de görüldüğ̈ gibi arazinin son derece parçalı bir görünüme sahip olmasını sağlamıştır. Medil mağarası ve çevresindeki alanlarda da görülen aşınım yüzeylerinin yarılmış ve parçalanmış görüntüsü Devrekani Çayı ve tabilerinin hızlı aşındırmasının bir sonucudur. Pleistosen'e ait karstik depresyonlar genellikle yapıya uygunluk göstermekte olup, bu oluşumda flüvyal süreçler de önemli etkiye sahiptir (Kurter, 1982;213). Bu süreç aynı zamanda yöredeki onlarca mağaranın oluşmaya başladı̆̆ dönem olarak da ifade edilebilir. Hem Devrekani Çayı ve tabilerinin aşındırma, taşıma ve biriktirme faaliyetleri sonucu vadilerini derinleştirmeleri hem de karstik depresyonların oluşum süreci içinde yeraltı drenajının gittikçe gelişmesi mağaraların oluşum sürecinin başladığına işaret etmektedir.

Karstik mağaralar genellikle benzer bir oluşum sürecine sahiptirler. Karstik mağaraların oluşumunda ana kayanın litolojik özellikleri, iklim, hidrografik özellikler, bitki örtüsü ve sahanın jeomorfolojik gelişimi önemli etkiye sahiptir. Karstik mağaralar, ana kayayı oluşturan kireçtaşlarının $\left(\mathrm{CaCO}_{3}\right)$ karbondioksitli $\left(\mathrm{CO}_{2}\right)$ sular tarafından eritilmesi ile meydana gelmiş büyük yeraltı boşluklarıdır. Mağaraların oluşumundaki kimyasal süreç şu şekilde formüle edilebilir: $\mathrm{CaCO}_{3}+\mathrm{H}_{2} \mathrm{O}+\mathrm{CO}_{2}=\left(\mathrm{HCO}_{3}\right)_{2}$. Bu olay geriye dönüşlü olup, ortam şartlarının değişmesine bağlı olarak, mağara içerisindeki damlataş1 oluşumuna imkân vermektedir (Uzun ve Zeybek, 1996;43).

Medil mağarasının oluşumunda, bol çatlaklı ve yarı kristalize kireçtaşlarının $\mathrm{CO}_{2}$ 'li sular tarafından çözünmesi yanında, sahanın tektonik yapısı da etkili olmuştur. Mağaranın gelişiminde birincil olarak kuzeydoğu-güneybatı yönlü, ikincil olarak da kuzey-güney yönlü kırık sistemleri etkili olmuştur. Ayrıca mağara içerisinde farklı doğrultularda uzanan çatlaklar da mağara oluşumunda etkili olan diğer bir etkendir. Mağara içerisinde çatlak sistemlerinin iyi geliştiği kesimlerde ise tavandan bazı blokların düşerek zeminde biriktiği görülmektedir. Bu durum mağaranın olgunluk aşamasında olduğunu göstermektedir.

Birçok karstik mağara gibi Medil mağarası da birkaç aşama geçirerek bugünkü durumuna gelmiştir. Başlangıç aşamasında atmosferi geçerken bir miktar bünyesine $\mathrm{CO}_{2}$ almış yağmur suları ve eriyen kar suları, çürümüş bitki atıkları ve topraktan geçerken $\mathrm{CO}_{2}$ bakımından daha da zenginleşirler. Karbonik asit içeren bu sular phreatik zonda (doygun zon) yeraltındaki güzergahları boyunca yüksek hidrostatik basınç altında ilerleyen suyun doğrudan kalkeri çözmesi sayesinde yeraltı boşluklarının oluşmasına neden olurlar (Nazik, 1989;57: Zeybek, 2001;245). Süreç içerisinde, doygun zonda oluşan mağara, Pleistosendeki taban seviyesinin düşmesini izleyen devrede bütünüyle havalandırma zonunda (Vados zon) kalmıştır. Bu durumun gerçekleşmesi ile mağaranın genişleme süreci durmuş, buna karşılık mağara içerisinde sarkıt, dikit, sütun ve flama gibi diğer şekillerin oluşumu gerçekleşmiştir. Mağara içerisindeki çatlaklardan halen suların sızması, mağara içerisindeki damlataş şekillerinin oluşum sürecinin devam ettiğinin göstergesidir 
(Foto 6). Üçüncü aşamada ise mağaranın tavan kısmından kopan bloklar salonlara düşmüş olup, bu durum mağaranın yavaş yavaş olgunluk dönemine girmiş olduğunu göstermektedir (Foto 7).



Foto 6. Medil mağarası içindeki sarkıtlar ve travertenlerden görünüm.

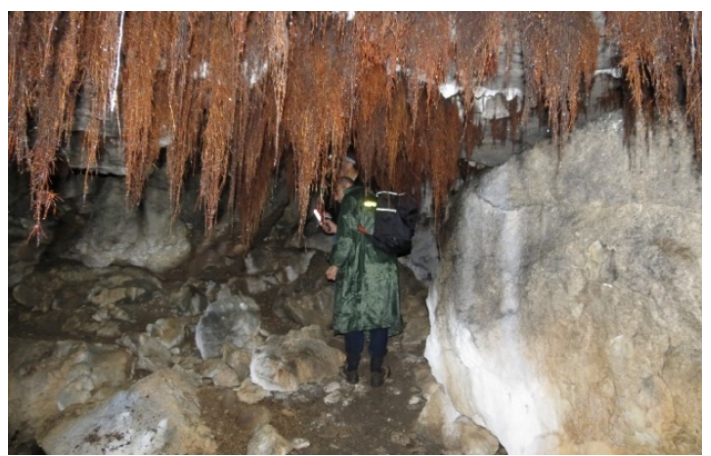

Foto 7. Medil mağarası girişinde tavandan kopan bloklar ve sarkan bitki kökleri.

\subsection{Mağaranın Şekli}

Medil mağarası, yatay yönde gelișmiș ve giriș kısmı ile mağara tabanı arasında yaklaşık 6 m'lik bir yükseklik farkının bulunduğu 4 ana salon ve bu salonların bağlantısını sağlayan galerilerden oluşmaktadır (Şekil 8,9). Toplam uzunluğu $205 \mathrm{~m}$ ve en geniş yeri $105 \mathrm{~m}$ olan Medil mağarasına kuzeybatıya bakan bir ağızdan girilmektedir. Mağaranın ağız kısmı çökmelere bağlı olarak iri bloklar ile oldukça daralmış durumdadır (Foto 8). Mağaranın ağız kısmından içeri yaklaşık $30^{\circ}$ lik bir eğimle $6 \mathrm{~m}$ kadar gidildikten sonra 3 ve 4 numaralı salonları birbirinden ayıran galeriye inilmektedir. Buradan kuzeybatı yönüne ilerlendikten sonra içinde iki adet sarnıcın da bulunduğu büyük salona gelinmektedir. Büyük salon yaklaşık $125 \mathrm{~m}$ uzunluk ve $72 \mathrm{~m}$ genişlik ile mağaranın en büyük boşluğunu olușturmaktadır. Sarnıçların bulunduğu yer büyük salonun dikey yönde en geniş bölümünü oluşturmakta olup burada yükseklik yaklaşı 4 m'dir. Buradan salonun kenar kısımlarına gidildikçe tavan hızla alçalmakta ve tavan yüksekliği yer $40 \mathrm{~cm}$ ye kadar düşmektedir.
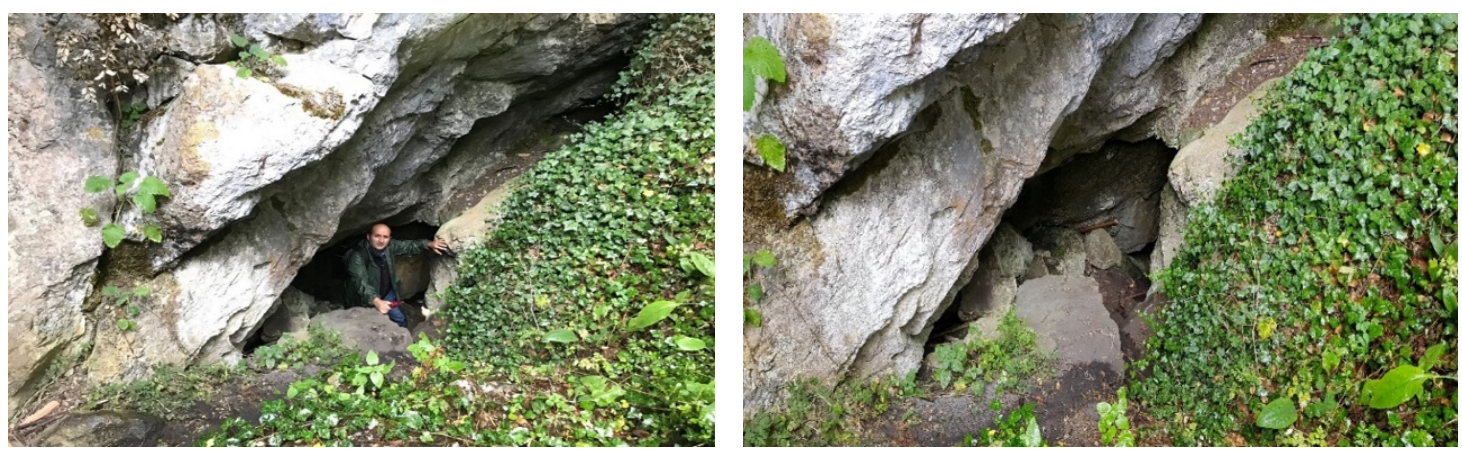

Foto 8. Medil mağarasının girişi. Yaklaşık $6 \mathrm{~m}$ lik eğimli girişi iri blokların tıkaması ile oldukça daralmıştır. 




Şekil 8. Medil mağarasının şematik planı. (ASPEG Anadolu Speleoloji Grubu tarafindan 2010 yılında hazırlanmış "Küre Milli Parkı Mağara Araştırma Sonuç Raporu" kapsamında Nuray ADA tarafindan çizimi yapılan haritadan değiştirilerek hazırlanmıştır.)

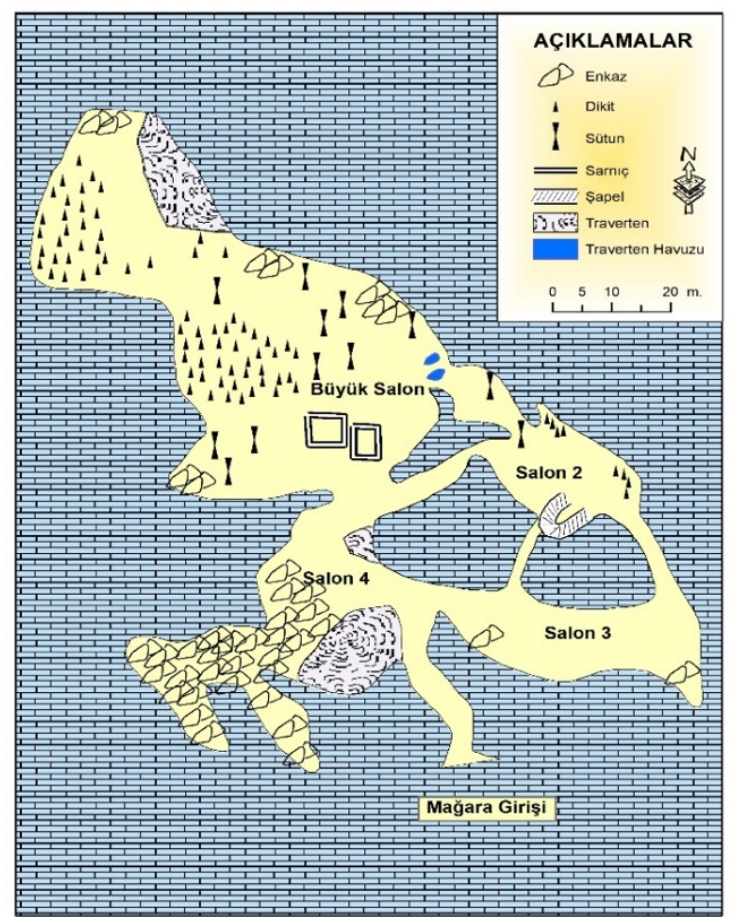

Şekil 9. Medil mağarasında damlataş şekillerini gösteren şematik plan. (ASPEG Anadolu Speleoloji Grubu tarafından 2010 yılında hazırlanmış "Küre Milli Parkı Mağara Araştırma Sonuç Raporu" kapsamında Nuray ADA tarafından çizimi yapılan haritadan değiştirilerek hazırlanmıştır.)

Büyük salonun batı ve kuzeybatısı sarkıt ve dikitler bakımından oldukça zengin iken özellikle orta, kuzey ve güney batı bölümünde çok sayıda irili ufaklı sütun bulunmaktadır. Büyük salondaki sütunlara ait bilgiler Tablo 3'de verilmiştir.

Tablo 3. Büyük salonda bulunan sütunların boyutları

\begin{tabular}{ccc}
\hline No & Sütün Yüksekliŏi & Sütun Capı $(\mathbf{c m})$ \\
\hline $\mathbf{1 -}$ & 190 & 55 \\
\hline $\mathbf{2}-$ & 175 & 140 \\
\hline $\mathbf{3 -}$ & 165 & 85 \\
\hline $\mathbf{4 -}$ & 160 & 110 \\
\hline $\mathbf{5 -}$ & 153 & 83 \\
\hline $\mathbf{6 -}$ & 148 & 96 \\
\hline $\mathbf{7 -}$ & 144 & 105 \\
\hline $\mathbf{8 -}$ & 135 & 86 \\
\hline $\mathbf{9 -}$ & 120 & 92 \\
\hline $\mathbf{1 0}$ & 100 & 45 \\
\hline
\end{tabular}

Tabloda da görüleceği üzere büyük salonda en büyüğü $190 \mathrm{~cm}$ ve en küçüğü $100 \mathrm{~cm}$ yüksekliğinde yaklaşık 10 kadar sütün bulunmaktadır. Bunların dışında özellikle mağaranın duvar kısımlarına yakın kesimlerinde daha küçük boyutta sütunlar da bulunmaktadır. Büyük salonun doğusunda oluşum gösteren bir diğer şekil ise traverten havuzudur. Bu kesimde ilki yaklaş1k $168 \mathrm{~cm}$ uzunluğunda, $82 \mathrm{~cm}$ genişliğinde ve $25 \mathrm{~cm}$ derinliğinde, ikincisi ise $108 \mathrm{~cm}$ uzunluğunda $66 \mathrm{~cm}$ genișliğinde ve $25 \mathrm{~cm}$ derinliğinde iki adet traverten havuzu bulunmaktadır. Büyük salondaki bir diğer oluşum ise kuzeybatı uç kısmında bulunan traverten oluşumudur. Yaklaşık $10 \mathrm{~m}$ uzunluğunda ve $3 \mathrm{~m}$ genişliğinde olan traverten mağaranın 
duvarından taban kısmına doğru kademeli olarak inmektedir. Büyük salon aynı zamanda geçmiște insanların yaşadığına dair iki adet sarnıcında bulunduğu yerdir (Foto 9). Bu sarnıçlardan batıda olanı $2 \mathrm{~m}$ uzunluğunda $1,53 \mathrm{~m}$ genişliğinde ve $1,22 \mathrm{~cm}$ derinliğinde bir küçük havuza benzemektedir. Bu büyük sarnıcın hemen yanında daha küçük bir sarnıç daha bulunmaktadır. Bu küçük sarnıcın uzunluğu 1,44 m, genişliği $0,83 \mathrm{~m}$ ve derinliği yaklaşık $1 \mathrm{~m}$ civarındadır. Büyük salondaki sarnıçların ile 2. salonda ibadet amacıyla yapılan şapelin duvar kalınlığı aynıdır. Bu tarihi eserlerde duvarlar yaklaşık $35 \mathrm{~cm}$ genişliğe sahiptir.


Foto 9. Medil mağarası içinde büyük salonun giriş kısmında su toplamak ve günlük ihtiyaçlarını karşılamak amacı ile yapılmış iki sarnıç (A, B) bulunmaktadır. Duvarları tahrip edilmiş olan bu sarnıçların parçalanan duvar kısımlarında yapım sırasında kullanılan tuğlalar (C) görülmektedir. Ayrıca yine tahribe uğramış Salon 2 de ibadet için kullanılan şapel (D) bulunmaktadır.

Medil mağarasındaki bu buluntular ile ilgili herhangi bir arkeolojik çalışmaya rastlanmamıştır. Ancak yörede 1995 yılında başlayan ve dönemler halinde devam eden Kültür ve Turizm Bakanlığı Kültür Varlıkları ve Müzeler Genel Müdürlüğü tarafından yürütülen yüzey araştırmaları projeleri kapsamında yöre ile ilgili bazı bilgilere rastlanılmıştır. 1995-1998 yılları arasında yapılan arkeolojik çalışmalar neticesinde Kastamonu ve çevresinin Paleolitik dönemden beri iskân edildiği ifade edilmektedir. Kalkolitik dönem ile İlk Tunç çağı I/II yerleşmelerinin genellikle üst üste bulunduğu ve küçük alan kaplayan yerleşmelerin daha çok $980 \mathrm{~m}$ ile $1200 \mathrm{~m}$ yüksekliğinde akarsulara yakın tepelik alanların yamaçlarında konumlandığı söylenmektedir (Özdoğan ve dĭ̆., 1998;228). Bakanlık tarafından 2009 yılında yürütülen projelerden birisi olan ve Azdavay yöresinin hemen kuzeyinde yer alan "Cide Arkeoloji Projesi" kapsamında yapılan çalışmanın sonucunda ise, yörede Mezolitik, Kalkolitik, Erken Tunç Devri I, M.Ö. İkinci binyıl, Demir Çağı ve Helenistik döneme ait arkeolojik izlerin bulunduğu belirtilmektedir. Aynı çalışmada yöredeki birçok mağara da Prehistorik ve Protohistorik dönemde yaşamın olduğuna dair kalıntılar bulunmuştur. Nitekim Medil mağarasında bulunan sarnıç ve şapel gibi tarihi kalıntıların (Foto 9), mağaraya kuş uçuşu yaklaşık 18 km mesafedeki Cide İlçesine bağlı Ortaca köyü yakınlarındaki Uçakdibi mağarası ve Kalafat köyü yakınlarındaki Gideros mağarasında da benzer tarihi kalıntılar ile çanak ve çömlekler bulunmuştur (During ve Glatz, 2010;192). 
Bu iki mağaranın içinde ve çevresinde kısmen kayaya oyulmuş şapel, duvarlara oyulmuş kürsüler, kubbeler ve duvarlara kazınmış haçlardan oluşan bir Hristiyan kompleksinin bulunduğu ifade edilmektedir. Mağaralardan elde edilen çanak-çömlekler daha çok Klasik ve Bizans dönemlerine tarihlidir (During ve Glatz, 2010;192). Aynı projenin 2010 yılında başlatılan ikinci etabında ize Azdavay yöresine daha yakın olan Şenpazar yöresinde yüzey araştırmaları yapılmıştır. Şenpazar ilçesine bağlı Çamdibi köyü yakınlarındaki Kılıçlı mağarasında yapılan arkeolojik çalışmalarda benzer sonuçlar vermiştir. Bu mağarada bulunan bazı kalıntıların yaşlandırılması sonucu mağaranın Erken Tunç devrinin son evresinden itibaren ilk yerleşmelerin başladığı bu araştırma neticesinde ortaya çıkarılmıştır (Düring ve dĭg., 2011;241).

Bütün bu çalışmaların sonuçları değerlendirildiğinde Medil mağarasının da bulundu bu bölgede uzun zamandan beri insanların yaşamakta olduğu görülmektedir. Arkeolojik yüzey araştırmaları yapılan mağaralara oldukça yakın olan Medil mağarasının da aynı dönemde yerleşilen mağaralardan birisi olduğu düşünülmekte olup, günümüzde tahrip edilmesine rağmen sarnıç ve şapel gibi kalıntılar da Erken Hristiyanlık dönemine ait izler taşımaktadır. Yine bu çalışmalarda "mağaradaki kalıntılar ile ilgili yoğun şekilde yasadışı kazılar ile tahrip edilmiştir” sorunu Medil mağarası içinde geçerli olup, sarnıç ve şapelin bulunduğu salonlarda kaçak kazılar yapıldığı tespit edilmiştir (Foto 10).

Dört ana salon ve bu salonları birbirine bağlayan galerilerden oluşan Medil mağarasında insanların çok uzun zaman yaşadıklarının bir diğer önemli kanıtı mağaranın iç kısmının ısınmak ve aydınlanmak amacı ile yakılan meşale ve ateşin mağaranın içerisinde yol açtığı kararmadır. Yakılan meşale ve diğer ateşlerden çıkan is mağaranın duvar ve damlataşı şekillerinin kararmasına yol açmıştır (Foto 11). Büyük salon başta olmak üzere mağaranın bütün bölümlerinde bulunan sarkıt, dikit, sütun, flama, mağara incisi gibi birçok oluşum bu isten etkilenerek siyah bir görünüm kazanmıştır. Mağaranın içinde daha yeni oluşumların ise beyaz ve sarı gibi normal renklerinde oldukları görülmektedir.
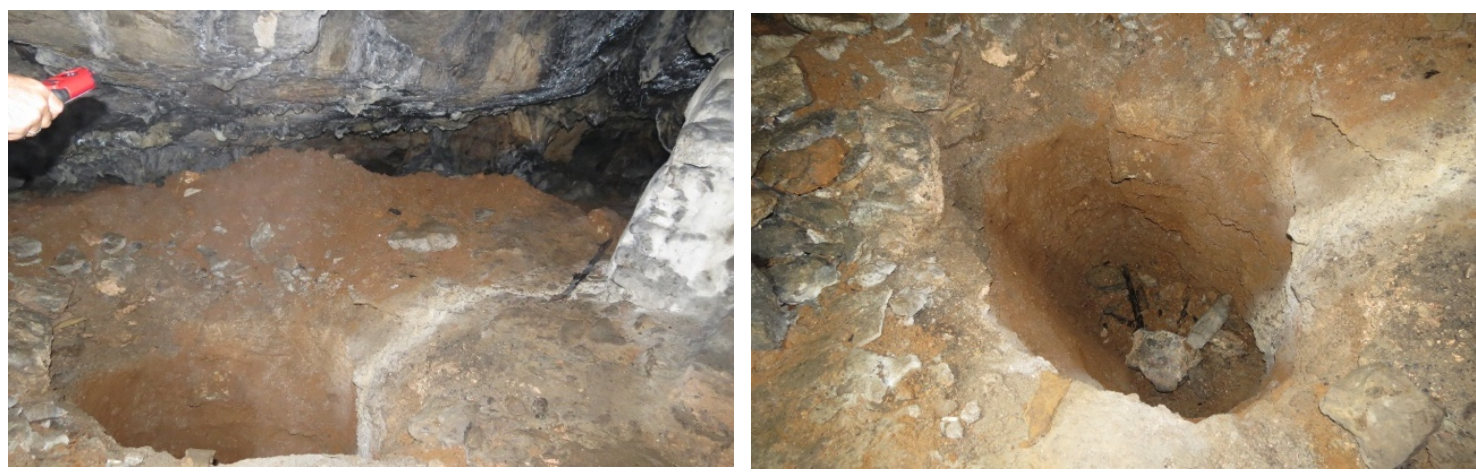

Foto 10. Medil mağarası içindeki sarnıç ve şapelin içinde yapılan kaçak kazılar bu kalıntılara büyük zarar vermiştir.
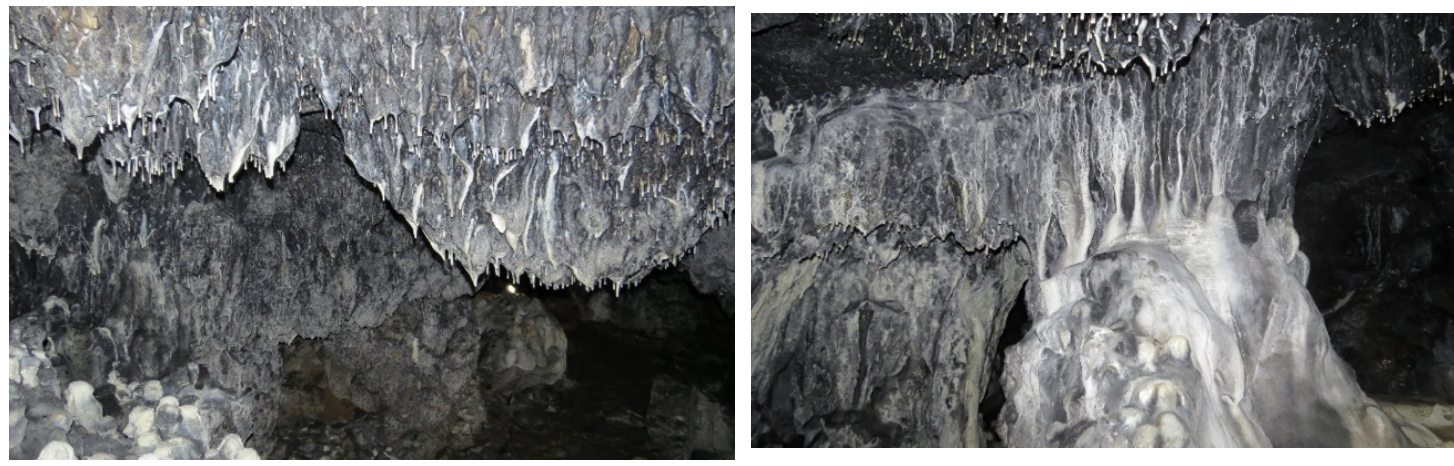

Foto 11. Medil mağarasında 1sınma ve aydınlanma amaçlı yakılan ateşler sonucunda mağaranın içi büyük oranda siyah bir görünüm almıştır. Sadece yeni oluşum gösteren yerlerde beyaz şekiller görülmektedir (Büyük salonun kuzeybatı ucu). 
Medil mağarasının 2. salonu yaklaşık $40 \mathrm{~m}$ uzunluğunda ve $17 \mathrm{~m}$ genişliğindedir. Tavan yüksekliği 3,5 m olan bu salon ibadet için kullanılan şapelin bulunduğu yerdir. Kapının giriş kısmından arka duvara kadar olan bölüm 2,5 m iken, eni 1,5 m dir. Yüksekliği $3 \mathrm{~m}$ olan şapelin duvar kalınlığ cm dir (Foto 9-D). Mağaranın bu bölümünde özellikle sarkıt ve flama şekilleri daha fazla görülmektedir. Mağaranın giriş kısmının doğu 3. salon bulunmaktadır. Yaklaşık $65 \mathrm{~m}$ uzunlukta ve $40 \mathrm{~m}$ genişlikte olan bu salonun tavan yüksekliği $2,6 \mathrm{~m}$ civarındadır. Bu salonun güneydoğu ve güney kısımlarında tavandan kopan iri bloklar zeminde bulunmaktadır (Foto 12). Bu salonda mağara incileri ve flama ve karpuz şekilli sarkıtların yoğunluk kazandığı görülmektedir (Foto 13).
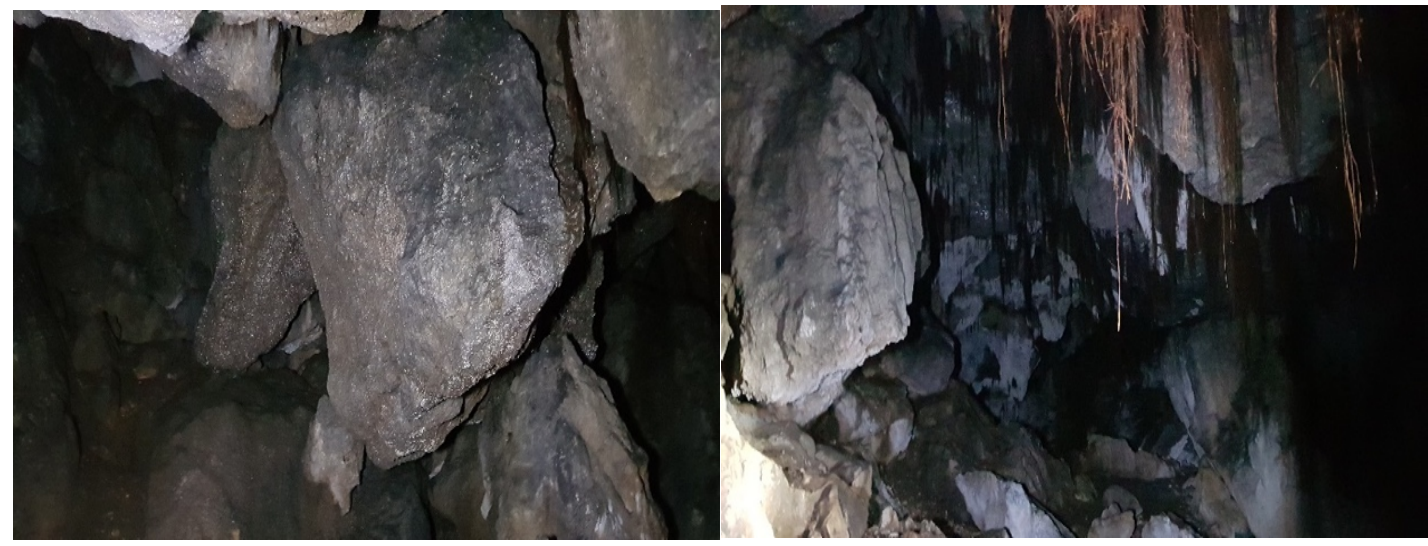

Foto 12. Medil mağarasının 3. salonunda tavandan kopan ve kopmak üzere olan iri bloklar.

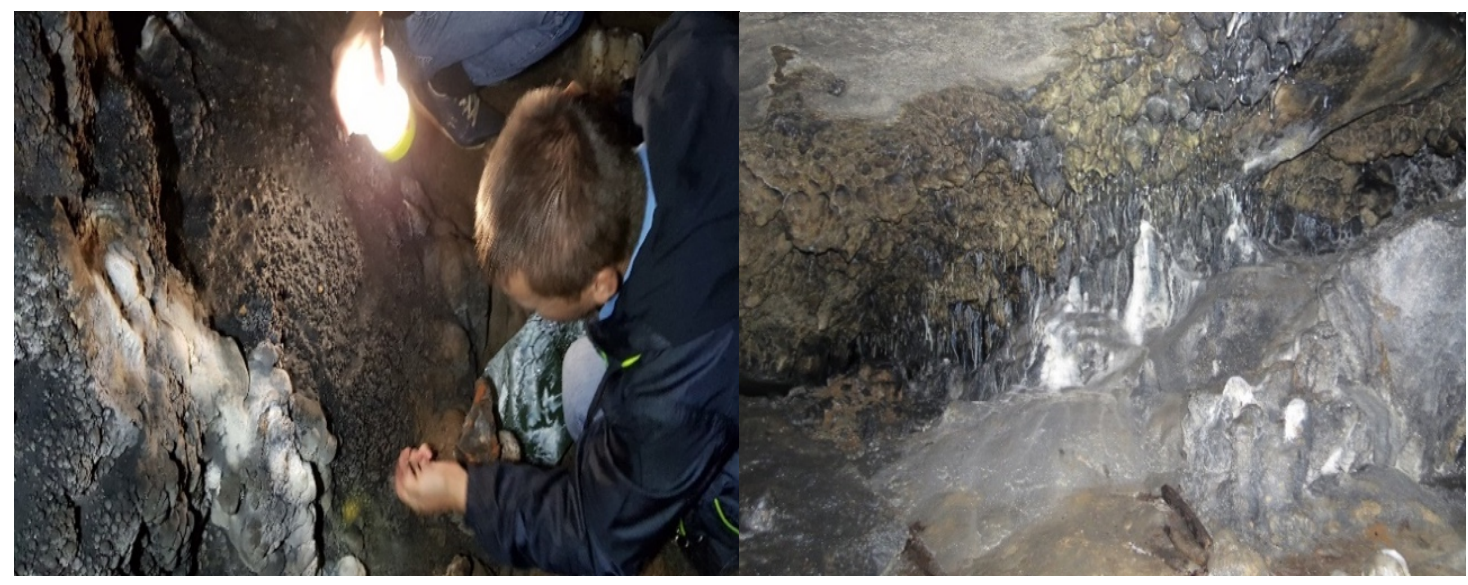

Foto 13. Medil mağarasının 3. salonu damlataşı şekilleri bakımından oldukça zengindir.

Medil mağarasının 4 salonu 63 m uzunluğunda ve 40 m genişliğindedir. Giriş bölümünde boyları 10-30 cm arasında değişen çeşitli sarkıt ve flamaların bulunduğu bu salon batıya doğru gittikçe alçalmaktadır. Ancak bu salonun büyük bölümü tavandan düşen moloz ve bloklar tarafından kaplıdır (Foto 14). Yürümenin dahi çok zor olduğu bu salonda güney batıya doğru iki galeri şeklinde boşluklar bulunmaktadır. Bir bütün olarak değerlendirildiğinde, yaklaşı $480 \mathrm{~m}^{2}$ lik iç alana ve 205 m'yi bulan uzunluğa sahip Medil mağarasının ağız kısmı ile büyük salonun tabanı arasında 2,5 m yükselti fark1 bulunmaktadır. 



Foto 14. Medil mağarasının 4. salonunda tavandan koparak zeminde biriken iri bloklar.

\subsection{Mağaranın Hava, Su ve Hayvan Varlığı}

Eylül ayında yapılan ölçümlere göre, mağaranın ağız kısmında sıcaklık $22{ }^{\circ} \mathrm{C}$ iken, sarnıçların bulunduğu büyük salon girişinde sıcaklık $18{ }^{\circ} \mathrm{C}$, büyük salonun en kuzeybatı ucunda ise sıcaklık $16{ }^{\circ} \mathrm{C}$ 'ye düşmektedir. Mağaradaki nem oranı ise sıcaklığın aksine mağaranın iç kesimlerine gidildikçe artmaktadır. Nitekim, mağaranın ağız kısmından girildikten sonra zeminde yapılan ilk ölçümde \% 80 olan nispi nem miktarı, sarnıçların olduğu büyük salonun giriş kısmında ve mağaranın en uç noktası olan büyük salonun kuzeybatısında ise \% 90 olarak ölçülmüştür. Mağaranın giriş kısmında nem oranının iç kesimlere göre düşük olması, bu kesimde dışarı ile hava dolaşımının daha fazla olması ile ilgilidir. Buna göre, mağaranın iç kısmı yaz mevsiminde dışarıya göre daha serin ve nispi nem miktarı daha fazladır. Bu değerlere göre mağaranın içerisi bir mikroklima alanı özelliği taşımaktadır.

Medil Mağarası, havalandırma zonunda bulunmakta, sürekli bir yeraltı akışına sahip bulunmadığ1 için de yarı aktif bir mağara karakteri göstermektedir. Bununla birlikte mağarada yağışlı dönemde yeraltı akışına ait izler de dikkati çekmektedir. Yaz devresinde, mağara içerisinde bulunan küçük traverten göllerin varlığı, traverten havuzlarının bazılarının içerisinde suyun bulunması ve sarkıtların uç kısmından suların damladığı gözlemlenmektedir. Mağara hayvan varlığı bakımından zengin değildir. İç kısmında bazı sinek türleri, örümcek ve böcekler bulunmaktadır.

\section{Medil Mağarasının Turizm Potansiyeli Ve Mağara Turizmi Açısından Önemi}

Turizm çekiciliği oluşturmaları bakımından Türkiye'de mağaralar önemli bir potansiyele sahiptir. Jeolojik yapısı ve kayaçların özelliği dikkate alındığında Türkiye arazisinin \%40’1 mağara oluşumu açısından önemli bir nitelik olan karstlaşmaya uygun kayaçlardan meydana gelmiştir (Arpacı ve diğ., 2012;61). Mağaralar, insanlar için doğal birer barınak olmalarının yanında, içindeki görsel güzellikler sunan damlataşı şekilleri, gezme ve sağlı amaçlı kullanım özellikleri ile günümüzün popüler turizm alanları karakteri kazınmışlardır (Nazik ve Güldalı, 1985: Uzun, 1991: Efe, 1999: Doğaner, 2001: Zeybek, 2001: Bekdemir vd., 2004: Ceylan, 2007: Sever, 2008: Karadeniz vd., 2009: Zeybek, 2010: Kinac1 vd., 2011: Özal ve Özcan, 2013: Doğanay, 2013: Öztürk vd., 2016: Nazik ve Poyraz, 2017). Medil mağaras1, farklı büyüklük ve şekil gruplarına sahip dört salonunda, görünümleriyle insanlarda hayranlık uyandıran farklı büyüklükte birçok damlataşı şekline sahiptir. Mağaranın duvarlarında oluşan travertenler, beyaz ve sarı renk ağırlıklı sarkıt, dikit, sütun oluşumlarının yanında flama, mağara incileri ve akma taşlar ile kaplıdır. Yine mağarada bulunan traverten havuzları güzel görüntüler oluşturmaktadır. Doğal özellikler bakımından önemli bir potansiyele sahip olan Medil mağarası, arkeolojik olarak da önemli bir alan özelliği göstermektedir. Mağara içerisinde bulunan ve eski dönemlerde insanların yaşadığının kanıtı olan tarihi eserler mağaranın cazibesini daha da arttırmaktadır.

Medil mağarasının turizme açılması hem yöre hem de bölge turizmi açısından önemli bir katkı sağlayacaktır. Ancak Türkiye'deki birçok mağara da yaşanan tahribat sorunlarının burada da yaşanmaması için bazı düzenlemelere ihtiyaç vardır. Turizm amacıyla kullanılmasına karar verilen bir mağarayı, gelişigüzel kullanıma açmak, mağaranın ve mağaranın içinde oluşan damlataşı şekillerinde geriye dönüşü olmayan büyük tahribata yol açacaktır. Bu durum sadece doğal oluşuma sahip şekiller için değil kültürel 
varlıklar içinde geçerlidir. Nitekim defineciler tarafından mağara içinde birçok kazı yapılmış ve mağara içindeki insan yaşamına ait izlere şahitlik eden buluntular büyük ölçüde tahrip edilmiştir. Bu nedenle Küre Dağları Milli Parkı sınırları içinde bulunan Medil mağarasının yöredeki diğer mağaralarla birlikte koruma altına alınması gerekmektedir. Mağaranın mevcut durumu ile hiçbir düzenleme yapılmadan turizme açılması ziyaretçiler açısından da büyük tehlikeler oluşturmaktadır. Mağaranın giriş kısmı ve içindeki salonların mevcut haliyle büyür risk oluşturduğu görülmektedir. Güvenliği sağlamak için aydınlatılma ve yürüyüş yolları yapılması yönlendirme tabelalarının konulması güvenlik açısından oldukça önemlidir. Bu nedenle Medil mağarasının korunması, gelen ziyaretçilerin güvenliklerinin sağlanması ve sürdürülebilir turizm için birçok düzenlemeyi içeren "Mağara Uygulama Projesi'nin" hazırlanması gereklidir. Bu tür projelerin hazırlanması ve uygulanması mağaranın korunması, herhangi bir tahribata uğramadan turizm faaliyetlerinde kullanılmasını esas alır. Bu tür uygulama projelerinin oluşturulmasında farklı uzmanlık alanlarından bilim insanlarının ortak çalışması önemlidir. Mağarayı turizme açacak yerel yönetimler tarafından jeolog, jeomorfolog, inşaat mühendisi, işletmeci, peyzaj mimarı gibi farklı alanlardan bilim insanlarının mağaranın turizme açılmamadan önce yapılacaklar hakkında çalışmaları ve düzenlemelerin buna göre yapılması büyük önem taşımaktadır.

Medil mağarasının da bulunduğu Kastamonu'nun Azdavay, Pınarbaşı, Şenpazar ve Cide yöreleri çok sayıda mağaraya ev sahipliği yapmakta olup bu mağaraların turizm potansiyeli hem damlataş1 şekillerinin yoğunluğu hem de arkeoljik olarak zengin bir mirasa sahip olmalarından dolayı oldukça yüksektir. Küre Dağları Milli Parkı sınırları içerisinde bulunan bu yöreler mağaralar yanında eşsiz güzelliğe sahip bitki örtüsü, kanyonları, akarsuları, şelaleleri gibi birçok doğal ve kültürel mirasa da sahiptir. Bütüncül bir yaklaşımla bu yörelerin yüksek turizm potansiyeli değerlendirilmeyi beklemektedir.

Bu kapsamda Medil mağarasının sahip olduğu çekiciliğin turizme kazandırılması Azdavay ilçesi turizmine önemli bir katkı sağlayacaktır. Bu durum, yöreye gelen turist ve ziyaretçilerin görebileceği istasyon sayısının artmasına da yol açacaktır. Medil mağarası ve yakın çevresinde yapılan arazi çalışmaları sırasında mağaranın turizme kazandırılabilmesinin önünde bazı sorunların olduğu saptanmıştır. Bu sorunların başında ulaşım en önemli sorunu teşkil etmektedir. Azdavay-Pınarbaşı devlet karayolunun 3. kilometresinden sonra asfalt yoldan Karakuşlu köy ayırımından sonra kısmen bozuk bir asfalt ve kısmen stabilize toprak yol başlamaktadır. Karakuşlu köyünü geçerek Ayvat mahallesine doğru yaklaşık 2 km bu bozuk yoldan devam edildikten sonra Mağara yolunu gösteren küçük bir tabeladan sonra sağa dönülmekte ve yol daha da kötüleşmektedir. Bu ayrımdan sonra yaklaşık $1 \mathrm{~km}$ oldukça bozuk ve tehlikeli Hüma tepesinin güney yamacında açılmış ve iki arabanın yan yana geçemediği yoldan ilerledikten sonra küçük araçların park edilebileceği bir düzlüğe gelinmektedir (Şekil 10). Burada Küre Dağları Milli Parkı tabelası bulunmakta olup, buradan sonra mağara ile ilgili hiçbir bilgi veya tabela bulunmamaktadır. Buraya kadar gelen ziyaretçilerin herhangi bir yönlendirme tabelası olmadığı için mağarayı ulaşmaları oldukça zordur. $\mathrm{Bu}$ park alanından sonra yaklaşık $1 \mathrm{~km}$ orman içindeki patika bir yol ile $1046 \mathrm{~m}$ giriş yüksekliğine sahip Medil mağarasına ulaşılmaktadır. Özellikle Karakuşlu köyünden sonra mağaraya ve yanı zamanda Çatak Kanyonu seyir terasına giden bu stabilize yolun mutlaka genişletilmesi ve asfalt hale getirilmesi gerekmektedir.

Yine mağaranın turizme kazandırılması ile ilgili önemli eksiklerden birisi de yeme, içme ve konaklama yerlerinin bulunmamasıdır. Yöreye gelen turistlerin yeme, içme ve konaklama ihtiyaçlarını karşılayabilecekleri ideal mekânlar bulunmayıp, sadece Azdavay ilçe merkezi bu ihtiyacı kısmen karşılayabilecek durumdadır. Mağara çevresinde bu ihtiyaçları karşılayacak mekanların oluşturulması turistlerin bu alanı tercih etmesi bakımından önemli bir yere sahiptir. Medil mağarası son dönemde oldukça popüler bir yer haline gelen Çatak Kanyonuna ve yeni yapımı tamamlanan seyir terasına (Foto 5) yakınlığı ayrıca bir avantaj olarak değerlendirilebilir. Çatak kanyonuna ve seyir terasına gelen turistler için Medil mağarası alternatif gezi güzergahlarından birisi olarak yöreye gelen turistlerin güzergahlarına dahil edilebilir. Doğal ve tarihi bir çekiciliği olan Medil mağarasının âtıl bir durumda kalmaması için mağaranın tanıtımına önem vermek gerekmektedir. 


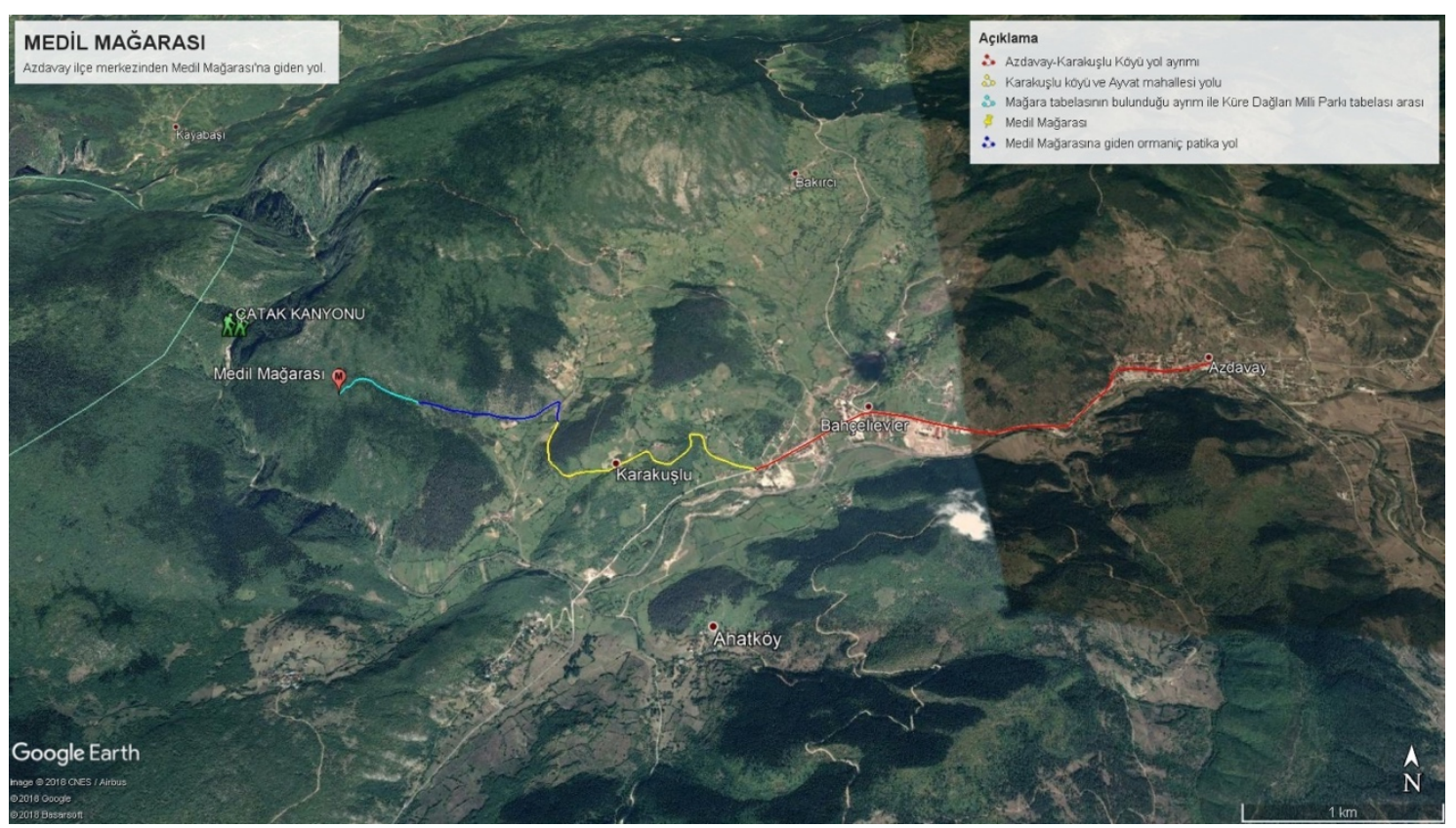

Şekil 10. Azdavay-Pınarbaşı karayolunda Karakuşlu köyü ayırımından itibaren mağaraya ulaşmak için izlenmesi gereken stabilize ve patika yolun Google Earth'dan alınmış görüntüsü.

Mağara ve çevresinin zengin bitki örtüsü ve yakınından geçen Devrekani Çayı bu anlamda değerlendirilmelidir. Öncelikli olarak iyi bir planlama yapılarak, sadece mağara ziyareti değil bununla birlikte yapılacak doğa yürüyüşleri ve doğa eğitim faaliyetleri gibi etkinlikler gelen turist sayısında artışa neden olacaktır. Bu kapsamda öncelikli olarak Medil mağarasının da içinde bulunduğu Azdavay yöresinin potansiyel turizm haritası oluşturulabilir. Bu haritalar oluşturulurken genellikle çevresinden bir takım farklı özellikleri nedeniyle ayrılan mekanların turizm potansiyelinin araştırılarak, envanterinin yapılması, bunların bilinmesi ve bilgilerin kılavuz haritalara yerleştirilmesi gerekmektedir (Efe vd., 2008; Özşahin ve Kaymaz, 2014).

\section{Sonuç ve Öneriler}

Medil mağarası potansiyeli yüksek doğal bir turistik kaynak olması nedeniyle jeosit ve jeomorfosit kapsamında değerlendirilebilir. Nitekim zengin damlataşı şekilleri ile karstik açıdan son derece önemli olan mağara, yörenin aynı zamanda yerleşme tarihine 1şık tutacak unsurlar da barındırması açısından önem taşımaktadır. Mağaranın daha fazla ziyaretçi çekebilmesi için gerek müstakil olarak, gerekse de Küre Dağları Milli Parkı ile ilgili çalışmalarda mağaranın da tanıtımı yapılmalıdır. Kastamonu ili ve Azdavay ilçesinde sadece ismi bilinen ancak nerede olduğu tam olarak bilinmeyen Medil mağarasının tanıtımı için mağaranın içinden çekilecek güzel görüntülerle hazırlanan broşür ve afişler bastırılmalı, mağaraya ulaşabilmek için yol güzergâhına tabelalar konulmalı, mağaranın turizm katologlarına girmesi için yerel ve ulusal turizm şirketleri ile iş birliğine gidilmeli ve yerel ve ulusal basın tarafindan tanıtılması, belgeseller hazırlanması sağlanmalıdır.

Medil mağarasının da bulunduğu bu alanın Küre Dağları Milli Parkı sınırları içerisinde bulunması ve koruma altına alınması turizme yönelik yapılacak planlamaların daha kapsamlı olmasını gerektirmektedir. Yörenin yer şekilleri dışında zengin bir ekosisteme sahip olduğu düşünüldüğünde mağara ve yakın çevresinde çeşitli ekoturizm faaliyetlerinin yapılması da mümkündür. Buna göre yapılacak düzenleme ve planlamalar neticesinde mağara çevresinde gelen turistlere yeme, içme ve dinlenme alanları oluşturulduktan sonra, mağara çevresindeki uygun alanlarda kamp alanları oluşturulup, trekking/doğa yürüyüşü, bisiklet turları, foto safari, tırmanma, macera turizmi, eğitsel faaliyetler ve yerel ürünlere dayalı olarak işleyen çeşitli ekoturizm etkinlikleri yapılabilir. Ayrıca mağara yakınındaki Devrekani Çayı bu kapsamda değerlendirilip, rafting ve balık avcılığ 1 etkinlikleri gibi faaliyetlerde yörenin ekoturizm gelişimi 
açısından öne çıkarılabilir. Bütün bu faaliyetlerin planlama ve uygulaması esnasında ise, doğal açıdan çok hassas bu tür alanların kontrollü ve dengeli bir şekilde kullanılması gerekmektedir.

Medil Mağarasının turizme açılmadan önce çevresinde birtakım düzenlemelerin yapılması, mağaranın çekiciliğinin artması ve alternatif turizm faaliyetlerinin hayata geçmesine katkı sağlaması bakımından önemlidir. Öncelikle mağaraya giden patika yol genişletilmeli, dinlenmek için alanlar oluşturulmalı ve çevre düzenlemesi yapılmalıdır. Yol yapımından sonra mağaranın giriş kısmı güvenlik altına alınmalıdır. Giriş kısmının kopan taş bloklarla oluşuyor olması ve bunların çok güvenli olmaması bu kısımda mutlaka bir düzenleme yapılmasını gerektirmektedir. Giriş kısmındaki bu düzenlemelerden sonra mağara içinin aydınlatılması ve gezi platformlarının oluşturulması gerekmektedir. Ayrıca, mağara bulunduğu alanın doğal özelliklerinin bozulmaması araç parkının yapıldığı alana otopark, yeme ve içme ihtiyaçlarının karşılanabileceği kafeterya, lokanta, tuvalet, vb. gibi küçük ve doğaya uyumlu tesislerin kurulmasi gerekmektedir.

\section{Kaynakça}

Akyol, Z., Arpat, E., Erdoğan, B., Göğer, E., Güner, Y., Şaroğlu, F., Şentürk, İ., Tütüncü, K., Uysal, Ş. (1974) Cide-Kurucaşile ile Dolayının Jeoloji Haritası. Maden Tetkik ve Arama Enstitüsü 1/50.000 Ölçekli Türkiye Jeoloji Haritaları Serisi.

Arpacı, Ö., Zengin, B., Batman, O. (2012) Karaman'ın Mağara Turizmi Potansiyeli ve Turizm Açısından Kullanılabilirliği. Karamanoğlu Mehmetbey Üniversitesi Sosyal ve Ekonomik Araştırmalar Dergisi, 14 (23), 59-64.

ASPEG (2010) Küre Milli Parkı Projesi Sonuç Raporu. Çevre Orman Bakanlığı Doğa Koruma ve Milli Parklar Genel Müdürlüğ̈̈, 9-11.

Atalay, İ. (1983) Türkiye Vejetasyon Coğrafyasına Giriş. Ege Üniversitesi Edebiyat Fakültesi Yayınları, 19.

Aygen, T. (1971) Mağaralar Nasıl Meydana Gelir. İller Bankası Dergisi, 45.

Bekdemir, Ü., Sever, R., Uzun, A., Elmacı, S. (2004) Yıldızkaya Mağarası. Doğu Coğrafya Dergisi, 9 (12), 311-326.

Ceylan, S., Demirkaya, H. (2006) Dim Mağarasının (Alanya) Kaynak Değerleri, Turizmde Kullanımı ve Sürdürülebilirliği. Doğu Coğrafya Dergisi, 15, 199-223.

Ceylan, S. (2007) Zeytintaşı Mağarası (Serik-Antalya). Doğu Coğrafya Dergisi, 12 (17), 223-243.

Doğanay, H., Zaman, S. (2013) Türkiye Turizm Coğrafyası. Ankara: Pegem Akademi (4. Baskı).

Doğaner, S. (2001) Türkiye Turizm Coğrafyası, Konya: Çizgi Kitapevi.

Doğu, A. F., Çiçek, İ., Gürgen, G., Tuncel, H., Somuncu, M. (1995) Periliin Mağarası. Ankara Üniversitesi Türkiye Coğrafyası Araştırma ve Uygulama Merkezi Dergisi, 3, 291-308.

DOPEM (2011) Küre Dağları Milli Parkı Ekosistem Tabanlı Fonksiyonel Orman Amenajman Planı Hazırlama Projesi (2011-2030). Ortadoğu Ormancıllk Proje Etüt ve Müşavirlik Ticaret A.Ş.

During, B., Glatz, C. (2010) 2009 Cide Arkeoloji Projesi: İlk Sonuçlar. Kültür ve Turizm Bakanllğg Kültür Varliklarl ve Müzeler Genel Müdürlüğ̈̈ 28. Araştırma Sonuçları Toplantısl, 1, 187-201.

Düring, B., Şerifoğlu, T. E., Glatz, C. (2011) 2010 Cide Arkeoloji Projesi: İkinci Sezon Sonuçları. Kültür ve Turizm Bakanlı̆̆ Kültür Varlıklarl ve Müzeler Genel Müdürlüğ̈̈ 29. Araştırma Sonuçları Toplantısl, 3, 237-250.

Efe, R. (1999) Dereköy Mağaraları ve Yakın Çevresinin Jeomorfolojik Özellikleri. Türk Coğrafya Dergisi, 34, 31-50.

Efe, R., Sönmez, S., Cürebal, İ., Soykan, A. (2008) Balıkesir'in Geoturizm Yöreleri: Marmara Geoturizm Örneği. 3. Ballkesir Ulusal Turizm Kongresi, 17-19 Nisan 2008. 
Ege, İ. (2015) Maymunlar Mağarası (Antakya-Hatay). Akademik Sosyal Araşttrmalar dergisi, 3 (15), 275 296.

Ertek, A. (1989) Sofular Mağarası (Şile-İstanbul). Atatürk Kültür, Dil ve Tarih yüksek kurumu Coğrafya Araştırmaları Dergisi, 1, 143-147.

Karadeniz, V., Çelikoğlu, Ş., Akpınar, V. (2009) Gökgöl Mağarası ve Turizm Potansiyeli. Turkish Studies International Periodical For the Languages, Literature and History of Turkish or Turkic, 4-8, 1621-1639.

Keçer, M., Ateş, S., Erkal, T., Karakaya, F. (2001) Kastamonu Merkez İlçesi ve Kentleşme Alanlarının Yerbilim Verileri. MTA Derleme No: 10454.

Ketin, İ. - Gümüş, O. (1962) Sinop-Ayancık Arasında III. Bölgeye Dahil Sahaların Jeolojisi Hakkında Rapor. TPAO Rapor No, 213.

Ketin, İ. - Gümüş, O. (1963) Sinop-Ayancık Arasında III. Bölgeye Dahil Sahaların Jeolojisi Hakkında Rapor. TPAO Rapor No, 288.

Kınacı, B., Pehlivan, A. N., Seyhan, G. (2011) Turizm ve Çevre (Çevre Koruma). Ankara: Pegem Akademi.

Kopar, İ. (2008) Elmalı Mağarası (İspir-Erzurum). Fırat Üniversitesi Sosyal Bilimler Dergisi, 18-2, 71-90.

Kopar, İ. (2010) Aladağların (Orta Toroslar) Fosil Mağara Potansiyelinden Yeni Bir Kayıt: Kapuzbaşı Mağarası (Divrik Dağı). Türk Coğrafya Dergisi, 54, 31-40.

Kurter, A. (1971) Kastamonu ve Çevresinin İklimi, İstanbul Üniversitesi Yayınları, 1627.

Kurter, A. (1982) Kastamonu ve Çevresinin Doğal Görünümü. İstanbul Üniversitesi Edebiyat Fakültesi Yayınları, 2930.

MGM. (2017) Devlet Meteoroloji İşleri Genel Müdürlüğü Yayımlanmamış Rasat Verileri.

MTA, (2010) Türkiye Jeoloji Haritaları Kastamonu-E30 ve D-30 Paftaları (1/100.000 Ölçekli). MTA Genel Müdürlüğü Jeoloji Etütleri Dairesi, 135.

Nazik, L.-Güldalı, N. (1985) İncesu Mağaralar Sistemi (Taşkale/Karaman); Jeomorfolojik Evrimi ve Ekonomik Olanakları. JeomorfolojiDergisi, 13, 47-52.

Nazik, L. (1989) Mağara Morfolojisinin Belirlediği Jeolojik-Jeomorfolojik ve Ekolojik Özellikler. Jeomorfoloji Dergisi, 17, 53-62.

Nazik, L. (2005) Mağara Nedir, Nasıl Oluşur? Ulusal Mağara Günleri Sempozyumu 24-26 Haziran, 125149.

Nazik, L. Poyraz, M. (2017) Türkiye Karst Jeomorfolojisini Karakterize Eden Bir Bölge: Orta Anadolu Platoları Karst Kuşağı. Türk Coğrafya Dergisi 68, 43-56.

Özdemir, Ü. (2005) Mencilis Mağarası. Doğu Coğrafya Dergisi, 13, 135-150.

Özdoğan, A., Marro, C., Tibet, A. (1998) Kastamonu Yüzey Araştırması 1997 Yılı Çalışmaları. Kültür Bakanlığı Anttlar ve Müzeler Genel Müdürlüğ̈̈ XVI. Araştırma Sonuçları Toplantısl, II, 219-237.

Öztürk, S., Tönük, G. U., Arıcak, B. (2012) Devrekani Çayı Alt Havzası'nın Doğal Kaynak Değerlerinin CBS ile Belirlenmesi. Kahramanmaraş Sütçü İmam Üniversitesi, Mühendislik Bilimleri Dergisi Özel Saylsı, 14-21.

Öztürk, M. Z., Şimşek, M., Utlu, M., Şener, M. F. (2016) Bolkar Dağlarının Batı Platosunun Flüvyo-Karstik Evrimi. TÜCAUM Uluslararası Coğrafya Sempozyumu. 106-115

Özal, T., Özcan, F. (2013) Çamlık Mağaraları ve Turizm Potansiyeli. Marmara Coğrafya Dergisi, 28, 423 443. 
Özşahin, E. (2013) Çan Mağarası'nın Jeomorfolojik Özellikleri ve Doğal Risk Açısından Değerlendirilmesi (Harbiye-Antakya/Hatay).Doğu Coğrafya Dergisi, 18 (29), 135-154.

Özşahin, E., Kaymaz, Ç. K. (2014) Gilindire (Aynalıgöl) Mağarası'nın Turizm Potansiyeli (AydıncıkMersin). Doğu Coğrafya Dergisi, 19 (31), 145-166.

Sakıcı, Ç., Çelik, S. (2017) Kastamonu'nun Mağara Turizmi Potansiyeli ve Görsel Etkisi. $1^{\text {st }}$ International Sustainable Tourism Congress 23-25 November, 171-178.

Sever, R. (2008) Polat mağarası ve Turizm Potansiyeli (Doğanşehir-Malatya). Doğu Coğrafya Dergisi, 13 (19), 251-266.

Sür, A. (1994). Karstik Yer şekilleri ve Türkiye'den Örnekler. Ankara Üniversitesi Türkiye Coğrafyası Araştırma ve Uygulama Merkezi Dergisi, 3, 1-28.

Uğuz, M. F., Sevin, M. (2010) Maden Tetkik ve Arama Genel Müdürlüğü 1/100.000 Ölçekli Türkiye Jeoloji Haritaları Kastamonu E30 ve D30 Paftaları, 135.

Uzun, A. (1991) Karaca Mağarası. Atatürk Kültür, Dil ve Tarih Yüksek Kurumu Coğrafya Bilim ve Uygulama Kolu, Coğrafya Araștırmaları Dergisi, 3, 15-23.

Uzun, A. - Zeybek, H. İ. (1996) Akçakale Mağarası (Gümüşhane). Türk Coğrafya Dergisi, 31, 39-53.

Uzun, A., Zeybek, H. İ., Yılmaz, C., Bahadır, M. (2015) Aksu Çayı Havzası Traferten Mağaraları (Giresun). Marmara Coğrafya Dergisi, 31,243-257.

Yılmaz, O. (1980) Daday-Devrekani Masifi Kuzeydoğu Kesimi Litostratigrafi Birimleri ve Tektoniği. Hacettepe Üniversitesi Yerbilimleri Dergisi, 5-6, 101-135.

Yılmaz, Y., Tüysüz, O. (1984) Kastamonu-Boyabat-Vezirköprü-Tosya Arasındaki Bölgenin Jeolojisi. Maden Tetkik ve Arama Genel Müdürlüğ̈̈, 7838.

Zeybek, H. İ. (2001) Bahçebaşı Mağarası (Turhal-Tokat). Doğu Coğrafya Dergisi, 7 (6), 237-253.

Zeybek, H. İ. (2010) Canik Dağlarının Güneydoğu Bölümünde Karstlaşma ve Karstik Şekiller. Doğu Coğrafya Dergisi, 15, 24, 273-288. 
Medil (Köklü) Mağarası (Azdavay-Kastamonu) ve Turizm Açısından Önemi 